\title{
Decoupling light harvesting, electron transport and carbon fixation during prolonged darkness supports rapid recovery upon re-illumination in the Arctic diatom Chaetoceros neogracilis
}

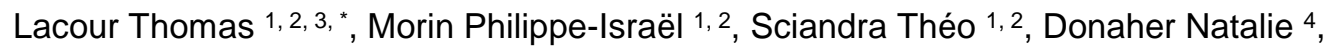 \\ Campbell Douglas A. ${ }^{4}$, Ferland Joannie ${ }^{1,2}$, Babin Marcel ${ }^{1,2}$
}

\author{
1 Takuvik Joint International Laboratory, CNRS (France) \& ULaval (Canada), Département de \\ BiologieUniversité LavalQuébec, Canada \\ 3 IFREMER, Physiol \& Biotechnol Algae LabsNantes Cedex 03, France \\ ${ }^{4}$ Department of BiologyMount Allison UniversitySackville, Canada \\ *Corresponding author : Thomas Lacour, email address : Thomas.Lacour@ifremer.fr
}

\begin{abstract}
:
During winter in the Arctic marine ecosystem, diatoms have to survive long periods of darkness caused by low sun elevations and the presence of sea ice covered by snow. To better understand how diatoms survive in the dark, we subjected cultures of the Arctic diatom Chaetoceros neogracilis to a prolonged period of darkness (1 month) and to light resupply. Chaetoceros neogracilis was not able to grow in the dark but cell biovolume remained constant after 1 month in darkness. Rapid resumption of photosynthesis and growth recovery was also found when the cells were transferred back to light at four different light levels ranging from 5 to $154 \mu \mathrm{mol}$ photon $\mathrm{m}-2 \mathrm{~s}-1$. This demonstrates the remarkable ability of this species to re-initiate growth over a wide range of irradiances even after a prolonged period in the dark with no apparent lag period or impact on survival. Such recovery was possible because $C$. neogracilis cells preserved their $\mathrm{Chl}$ a content and their light absorption capabilities. Carbon fixation capacity was down-regulated (ninefold dark decrease in PCm) much more than was the photochemistry in PSII (2.3fold dark decrease in ETRm). Rubisco content, which remained unchanged after one month in the dark, was not responsible for the decrease in PCm. The decrease in PSIl activity was partially related to the induction of sustained non-photochemical quenching (NPQ) as we observed an increase in diatoxanthin content after one month in the dark.
\end{abstract}

Keywords : Arctic microalgae, Polar night, Diatom, Darkness, Photosynthesis, Growth rate, Temperature 


\section{Acknowledgment}

27 We thank a joint contribution to the research programs of UMI Takuvik, ArcticNet (Network

28 Centres of Excellence of Canada), the Canada Excellence Research Chair in Remote Sensing of

29 Canada's New Arctic Frontier, and the Canada Research Chair program. 
50

51

52

53

54

55

56

57

58

59

60

61

62

63

64

65

66

67

68

69

70

71

72

73

74

75

76

77

78

79 80 of energy reserves (Peters 1996, Peters and Thomas 1996, Schaub et al. 2017). Diatoms can store

\section{Introduction}

Diatoms are ubiquitous in the surface ocean, including at very high latitudes in the Arctic where they are the most abundant microalgae in ice and in the phytoplankton community (Poulin et al. 2011). During winter, light in the surface ocean is very low due to low sun elevations and the presence of sea ice generally covered by snow (McMinn et al. 1999, Mundy et al. 2009, Leu et al. 2015). Several studies have reported on the ability of polar diatoms to survive long periods of darkness and resume fast growth as soon as light becomes available (Smayda and Mitchell-Innes 1974, Palmisano and Sullivan 1982, 1983, Peters and Thomas 1996, McMinn et al. 1999, Wulff et al. 2008, McMinn and Martin 2013, Fang and Sommer 2017). Our study provides new insights on the physiological mechanisms of dark survival and recovery.

Various strategies may allow microalgae to cope with darkness. Several microalgae taxa develop resting stages, including cysts and spores that remain viable for up to a hundred years in the case of dinoflagellates (Lundholm et al. 2011). Nutritional versatility is another strategy whereby microalgae can use both photoautotrophy and heterotrophy to obtain energy (mixotrophy). The heterotrophic capacity of polar diatoms increases as cells go into a simulated polar night (Palmisano and Sullivan 1982). Polar diatoms can assimilate amino acids and glucose both in the light and in the dark (Rivkin and Putt 1987). Some diatoms are even capable of net heterotrophic growth in the presence of glucose (White 1974). However, to our knowledge, net heterotrophic growth of a polar diatom during a prolonged period of darkness has not been observed and the addition of organic substrates does not appear to aid their dark survival capabilities (Dehning and Tilzer 1989, Popels and Hutchins 2002).

72 Our current knowledge of the physiology of dark survival derives mostly from studies using non-

73 Arctic diatoms, or from other algal groups. For instance, green algae seem to partially dismantle 4 their photosynthetic apparatus during long periods in the dark but keep it loosely assembled to 5 rapidly resume photosynthesis when exposed to light (Baldisserotto et al. 2005, Morgan-Kiss et al. 6 2006, Ferroni et al. 2007, Nymark et al. 2013). In natural communities, photosynthetic performance

77 falls to minimal levels after several weeks of darkness (Reeves et al. 2011, Martin et al. 2012) while 8 generally going back to a normal state nearly immediately upon the return of light (Kvernvik et al. 79 2018). In diatoms, dark survival is also characterized by low metabolic rates and the consumption 
81 large quantities of lipids to buffer energy shortage (Smith and Morris 1980, Palmisano and Sullivan

82 1982), so a balance between energy storage and the rate of utilization may be tuned to increase

83 survival during long periods of darkness.

84

85 In the Arctic marine environment, changes in snow optical properties was shown to be the primary

86 driver for allowing sufficient light to penetrate through the thick snow and initiate algae growth

87 below the sea ice (Hancke et al. 2018). Light increase can also be abrupt because of sea ice breakup

88 and can take place at different moments of the spring and summer. Polar diatoms must thus cope

89 with long period in darkness (or very low irradiance) and sudden light bursts of unpredictably

90 variable intensity even after prolonged darkness. The physiological basis of such flexibility is

91 mostly unknown. Several recent studies have examined the physiological response of polar

92 microalgae to changes in growth irradiance (Kropuenske et al. 2009, Arrigo et al. 2010,

93 Kropuenske et al. 2010, Mills et al. 2010, Petrou et al. 2010, Petrou et al. 2011, Petrou and Ralph

94 2011, van de Poll et al. 2011, Lacour et al. 2018). These studies highlighted how non-

95 photochemical quenching (NPQ) is a crucial physiological mechanism for the survival of polar

96 diatoms at low temperature coupled with other stresses such as high light (including UV radiations)

97 (Petrou et al. 2016). Lacour et al. (2018) have shown, in the Arctic diatom Thalassiosira gravida

98 acclimated to high irradiance, a strong sustained (hour kinetics relaxation) non photochemical

99 quenching (NPQs). NPQ (and possibly NPQs) may play an important role to prime diatoms for

100 sudden transitions from dark to (variable) light exposure. The purpose of this study was to describe

101 the physiological strategy that allows polar diatoms to survive in the dark while remaining prepared

102 for light return.

103

104 We first studied the growth and photophysiology at four different growth irradiances of 105 Chaetoceros. neogracilis, one of the dominant diatoms in the Beaufort Sea (Balzano et al. 2012, 106 Balzano et al. 2017) after one month in darkness. To understand how C. neogracilis manage such 107 recovery, we described in detail the physiological state of the cells after one month in the dark from 108 light capture to carbon fixation.

109

\section{Material and methods}

111 Algal Cultures 
113 We performed two independent experiments: a light recovery experiment (Exp 1) and a dark

114 acclimation experiment (Exp 2). In Exp 1, unialgal cultures of C. neogracilis (Roscoff Culture

115 Collection RCC 2278), isolated during the Malina cruise (2009) in the Beaufort sea (Balzano et al.

116 2012) were grown in semi-continuous cultures of $2000 \mathrm{~mL}$ in pre-filtered $\mathrm{f} / 2 \mathrm{medium}$ (Guillard

117 1975) enriched with silicate. Salinity was 35 PSU. The illumination was provided continuously by

118 white fluorescent tubes at $23 \mu \mathrm{mol}$ photon $\mathrm{m}^{-2} \mathrm{~s}^{-1}$ as measured using a QSL-100 quantum sensor

119 (Biospherical Instruments, San Diego, CA, USA) placed in the culture vessel. Culture conditions

120 were maintained semi-continuously by diluting cultures once a day in order to maintain biomass

121 semi-constant (MacIntyre and Cullen 2005) and gently aerated through $0.3 \mu \mathrm{m}$-pore-filters.

122 Cultures were grown in a growth chamber (Percival Scientific Inc., Perry, IA, USA) that allowed

123 temperature maintenance at $0^{\circ} \mathrm{C}\left( \pm 1^{\circ} \mathrm{C}\right)$. Triplicate cultures were then incubated in complete

124 darkness for 30 days and then illuminated by white fluorescent tubes (Phillips®, 54W/840) at 4

125 different light levels (L/D, 12h/12h) with mean daily irradiances of 5, 27, 41, and $154 \mu$ mol photon

$126 \mathrm{~m}^{-2} \mathrm{~s}^{-1}( \pm 5 \%)$ and maximum irradiances (at noon) of 531, 141, 93 and $17 \mu \mathrm{mol}$ photon $\mathrm{m}^{-2} \mathrm{~s}^{-1}$ (see

127 Online resource 1) controlled by a specific sofware (IntellusUltraConnect, Percival Scientific Inc.,

128 Perry, IA, USA). Those irradiances roughly correspond to the mean daily irradiances encountered

129 between 70 and $80^{\circ} \mathrm{N}$ in March, April, May and June respectively (seasonal change in day length

130 was not mimicked due to technical considerations). We monitored cell number and photochemical

131 characteristics over 8 to 14 days following re-illumination (Experiment 1: light recovery).

132 Triplicate culture were sampled at the first sunrise ( $t 0)$ and several time during the first light period.

133 Then, the cultures were sampled each day at noon.

135 In Exp 2, triplicate cultures were also acclimated to $23 \mu \mathrm{mol}$ photon $\mathrm{m}^{-2} \mathrm{~s}^{-1}$ (continuous light) or 136 to complete darkness for 30 days before sampling for comparisons of cell number, pigments, 137 particulate carbon and nitrogen, carbon fixation, Photosystem II (PSII) photochemical activity and 138 Rubisco content (RbcL) (Experiment 2: dark acclimation). 
142 Chaetoceros neogracilis cells were counted and sized (equivalent spherical diameter) before and 143 after culture dilution using a Beckman Multisizer 4 Coulter Counter. The concentrations of 144 particulate $\mathrm{C}$ and $\mathrm{N}$ were determined daily on triplicate samples. For particulate carbon and 145 nitrogen, an aliquot of $10 \mathrm{~mL}$ of algal culture was filtered onto glass-fiber filters $(0.7 \mu \mathrm{m}, 25 \mathrm{~mm})$ 146 pre-combusted at $500^{\circ} \mathrm{C}$ for $12 \mathrm{~h}$. Filters were kept desiccated before elemental analysis with a 147 CHN analyzer (2400 Series II CHNS/ O; Perkin Elmer, Norwalk, CT, USA). For pigment analysis, 148 an aliquot of algal culture $(5 \mathrm{~mL})$ was filtered onto a GF/F glass-fiber filter, immediately flash149 frozen in liquid nitrogen and stored at $-80^{\circ} \mathrm{C}$ until analysis by HPLC using the protocol described 150 in Zapata et al. (2000). Sample filtration were done as fast as possible ( $<2 \mathrm{~min}$ ) under very low 151 green light. The xanthophyll de-epoxidation state (DES in \%) was calculated as Dt/(Dd + Dt)*100, 152 where Dd is the concentration of Diadinoxanthin, the epoxidized form and Dt is that of 153 Diatoxanthin, the de-epoxidized form (Lavaud et al. 2007).

\section{Carbon fixation}

157 The relationship between the rate of carbon fixation (P) and irradiance (E) (P vs E curve) was 158 determined according to Lewis and Smith (1983). A 50-mL sample was collected in each replicate 159 culture, and inoculated with inorganic $\left.{ }^{14} \mathrm{C}_{\left(\mathrm{NaH}^{14} \mathrm{CO}_{3}, 2 \mu \mathrm{Ci} \mathrm{mL}\right.}{ }^{-1}\right)$. To determine the total amount 160 of bicarbonate added, three $20-\mu \mathrm{L}$ aliquots of inoculated culture sample were added to $50 \mu \mathrm{L}$ of an 161 organic base (ethanolamine) and $6 \mathrm{ml}$ of the scintillation cocktail (Ecolume) into glass scintillation 162 vials. Then $1-\mathrm{mL}$ aliquots of the inoculated culture sample were dispensed into twenty-eight $7-\mathrm{mL}$ 163 glass scintillation vials already cooled in their separate thermo-regulated cavities $\left(0\right.$ or $\left.5^{\circ} \mathrm{C}\right)$. The 164 vials were exposed to 28 different light levels provided by independent LEDs (LUXEON Rebel, 165 Philips lumileds) from the bottom of each vial. The PAR ( $\mu$ mol photon $\left.\mathrm{m}^{-2} \mathrm{~s}^{-1}\right)$ in each cavity was 166 measured before incubation with an irradiance meter (Biospherical QSL-100) equipped with a $1674 \pi$ spherical quantum sensor. After 20 minutes of incubation, culture aliquots were fixed with 50 $168 \mu \mathrm{L}$ of buffered formalin then acidified $(250 \mu \mathrm{L}$ of $\mathrm{HCl} 50 \%)$ under the fume hood for 3 hours in 169 order to remove the excess inorganic carbon (JGOFS protocol, UNESCO 1994). Finally, $6 \mathrm{~mL}$ of 170 scintillation cocktail were added to each vial prior to counting in the liquid scintillation counter 171 (Tri-Card, PerkinElmer). The chlorophyll-specific carbon fixation rate was finally computed 172 according to Parsons et al. (1984). 


\section{Fluorescence measurements}

175

176 Photochemical properties of PSII were determined by variable fluorescence using a Fluorescence 177 Induction and Relaxation (FIRe) fluorometer (Satlantic, Halifax, NS, Canada) that applies a

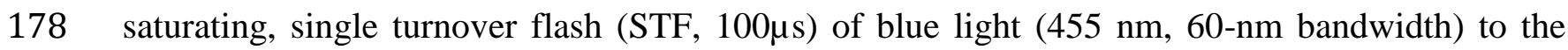
179 incubated sample to generate a fluorescence induction curve (detected at $680 \mathrm{~nm}$ ) that can be used 180 to estimate the minimum fluorescence ( $F_{0}$ for dark-adapted and $F_{S}$ for light-adapted samples), the 181 maximum fluorescence ( $\mathrm{F}_{\mathrm{m}}$ if dark-adapted and $\mathrm{F}_{\mathrm{m}}$ ' if light-adapted) and the effective absorption 182 cross section of PSII ( $\sigma_{\text {PSII }}$ if dark-adapted and $\sigma^{\prime}{ }_{\text {PSII }}$ if light-adapted) using the FIReWORX 183 algorithm (Pers. Comm. Audrey Barnett, www.sourceforge.net) and the flash lamp calibration 184 provided by the instrument manufacturer (Thomas and Campbell 2013). We found that 20 min in darkness was sufficient to fully relax non-photochemical quenching of $F_{0}$ and $F_{m} . F_{s}, F_{m}$ ' and $\sigma$ 'PSII

186 were measured repeatedly on the same culture subsample after 2 min exposures under an increasing 187 range of actinic light levels.

189 We estimated the maximum quantum yield of PSII $\left(\mathrm{F}_{\mathrm{v}} / \mathrm{F}_{\mathrm{m}}\right)$ and the optical absorption cross section 190 ( $\sigma_{\text {PSII }}^{\text {OPT }}$ from 20 min dark acclimated cells (Huot and Babin 2010) and the realized quantum yield 191 of charge separation at the PSII (ФPSII, Genty et al. (1989)) as:

\section{Equation 1}

\section{Equation 2}

$$
\Phi_{\mathrm{PSII}}=\frac{\mathrm{F}_{\mathrm{m}^{\prime}}-\mathrm{F}_{\mathrm{S}}}{\mathrm{F}_{\mathrm{m}^{\prime}}}
$$

\section{Equation 3}

199 To quantify the partitioning of excitation energy between photochemistry, fluorescence and 200 thermal dissipation, we used the approach of Hendrickson et al. (2004). ФPSII corresponds to the 201 fraction of absorbed irradiance used for photochemistry, $\Phi_{\mathrm{f}, \mathrm{D}}$ is the sum of the fractions that are 
202 lost by either thermal dissipation or fluorescence and $\Phi_{\mathrm{NPQ}}$ is the fraction that is thermally 203 dissipated via $\Delta \mathrm{pH}$ and/or xanthophyll-regulated processes:

$204 \Phi_{\mathrm{f}, \mathrm{D}}=\frac{\mathrm{F}_{\mathrm{s}}}{\mathrm{F}_{\mathrm{m}}}$

\section{Equation 4}

205 and

$206 \Phi_{\mathrm{NPQ}}=\frac{\mathrm{F}_{\mathrm{s}}}{\mathrm{F}_{\mathrm{m}^{\prime}}}-\frac{\mathrm{F}_{\mathrm{S}}}{\mathrm{F}_{\mathrm{m}}}$

\section{Equation 5}

207

208

209

The PSII specific electron transport rate (ETR, $\mathrm{e}^{-}$PSII $^{-1} \mathrm{~s}^{-1}$ ) was calculated as (Suggett et al. 2010):

$\mathrm{ETR}=\sigma_{\mathrm{PSII}} \cdot \frac{\boldsymbol{\Phi}_{\mathrm{PSII}}}{\mathbf{F}_{\mathrm{v}} / \mathbf{F}_{\mathbf{m}}} \cdot \mathrm{E} \cdot 6.02210^{-3}$

\section{Equation 6}

210 where $\mathrm{E}$ is the actinic irradiance $\left(\mu \mathrm{mol}\right.$ photon $\left.\mathrm{m}^{-2} \mathrm{~s}^{-1}\right)$, $\sigma_{\mathrm{PSII}}$ is the effective absorption cross-section

211 of PSII $\left(\mathrm{A}^{2} \mathrm{PSII}^{-1}\right)$ measured from dark acclimated samples and $6.02210^{-3}$ is a constant to convert

212 бPSII to $\mathrm{m}^{2} \mu \mathrm{mol}$ photon ${ }^{-1}$.

213

214 A proxy for the amount of active PSII was estimated as (Oxborough et al. 2012, Silsbe et al. 2015,

215 Murphy et al. 2017):

216 PSII chl $\mathrm{a}^{-1} \sim \mathrm{k} \times \frac{\mathrm{F}_{\mathrm{O}}}{\sigma_{\mathrm{PSII}} \times[\mathrm{Chl} \mathrm{a}]}$

\section{Equation 7}

217 where $\mathrm{k}$ is an unknown constant.

218

219 Data analysis. The initial slope $\left(\alpha, \mathrm{g} \mathrm{C} \mathrm{g}^{-1} \mathrm{Chl} a \mathrm{~h}^{-1}\left(\mu \mathrm{mol} \text { photon } \mathrm{m}^{-2} \mathrm{~s}^{-1}\right)^{-1}\right.$ and $\alpha^{\mathrm{ETR}}, \mathrm{e}^{-} \mathrm{PSII}^{-1}$ $\left.220\left(\mu \text { mol photon } \mathrm{m}^{-2}\right)^{-1}\right)$ and the maximum value of the rate versus E curves $\left(\mathrm{P}_{\mathrm{m}}, \mathrm{d}^{-1}\right.$ and ETR $\mathrm{m} \mathrm{e}^{-}$PSII $^{-}$ $221{ }^{1} \mathrm{~s}^{-1}$ ) were estimated by fitting the equation of Platt et al. (1980) (with the photoinhibition parameter $222 \beta)$ to the experimental rate and PAR values as:

$223 \quad \mathrm{P}=\mathrm{P}_{\mathrm{m}}\left(1-\mathrm{e}^{-\frac{\alpha \mathrm{E}}{\mathrm{P}_{\mathrm{m}}}}\right) \mathrm{e}^{-\frac{\beta \mathrm{E}}{\mathrm{P}_{\mathrm{m}}}}$

\section{Equation 8}

$224 \quad \mathrm{ETR}=\mathrm{ETR}_{\mathrm{m}}\left(1-\mathrm{e}^{-\frac{\alpha_{\mathrm{ETR}}}{\mathrm{ETR} m}}\right) \mathrm{e}^{-\frac{\beta^{\mathrm{ETR}} \mathrm{E}}{\mathrm{ETR} m}}$

\section{Equation 9}

225

226 The light-saturation parameters for carbon fixation $\left(E_{K}, \mu \mathrm{mol}\right.$ photon $\left.\mathrm{m}^{-2} \mathrm{~s}^{-1}\right)$ and for electron 227 production at PSII $\left(\mathrm{E}_{\mathrm{K}}^{\mathrm{ETR}}, \mu \mathrm{mol}\right.$ photon $\left.\mathrm{m}^{-2} \mathrm{~s}^{-1}\right)$ were obtained as:

$228 \quad \mathrm{E}_{\mathrm{K}}=\frac{\mathrm{P}_{\mathrm{m}}}{\alpha}$

Equation 10

229

$$
\mathrm{E}_{\mathrm{K}}^{\mathrm{ETR}}=\frac{\mathrm{ETR}_{\mathrm{m}}}{\alpha^{\mathrm{ETR}}}
$$

\section{Equation 11}




\section{Protein analyses}

233 For RbcL quantitation, $30 \mathrm{~mL}$ of each culture was harvested onto GF/F filters $(0.7 \mu \mathrm{m}$ pore size, 234 Whatman). Filters were flash-frozen in liquid nitrogen and stored at $-80^{\circ} \mathrm{C}$. Protein extractions 235 were performed using the FastPrep-24 and bead lysing "matrix D" (MP Biomedicals), using 4 236 cycles of $60 \mathrm{~s}$ at $6.5 \mathrm{~m} / \mathrm{s}$ in $750 \mu \mathrm{L}$ of $1 \mathrm{X}$ extraction buffer (Agrisera, AS08 300). The supernatant 237 was assayed using a detergent compatible (DC) assay kit against BGG standard (Biorad), then 238 equalized volumes containing $0.25 \mu \mathrm{g}$ of denatured total protein containing $1 \mathrm{x}$ sample buffer 239 (Invitrogen) and $50 \mathrm{mM}$ DTT were loaded onto a 4-12\% Bis Tris SDS-PAGE gel (Invitrogen). 240 Each gel was also loaded with a 5-point quantitation curve using RbcL molar standard 241 (www.agrisera.se, AS01 017S).

243 Proteins were separated via electrophoresis at $200 \mathrm{~V}$ then transferred to polyvinylidene difluoride 244 (PVDF) membranes at $30 \mathrm{~V}$. Membranes were blocked for $1 \mathrm{~h}$ in $2 \% \mathrm{w} / \mathrm{v}$ ECL blocking agent (GE 245 Healthcare) dissolved in TBS-T (Tris, $20 \mathrm{mM}$; NaCl, $137 \mathrm{mM}$; Tween-20, 0.1\% $/ \mathrm{v}$ ), then incubated 246 in 1:20,000 rabbit polyclonal anti-RbcL antibody for $1 \mathrm{~h}$ (Agrisera, AS03 037) and finally in 247 1:20,000 goat anti-rabbit IgG HRP conjugated antibody (Agrisera, AS10 668) for $1 \mathrm{~h}$. Membranes 248 were rinsed with TBS-T solution five times after each antibody incubation. Chemiluminscent 249 images were obtained using ECL Ultra reagent (Lumigen, TMA-100) and a VersaDoc CCD imager

250 (Bio-Rad). Band densities for samples were determined against the standard curve using the 251 ImageLab software (v 4.0, Biorad).

252

253 Apparent Rubisco catalytic turnover rate $\left(\mathrm{C} \mathrm{RbcL}^{-1} \mathrm{~s}^{-1}\right)$ was computed as $\mathrm{Wu}$ et al. (2014):

254 RUBISCO catalytic turnover rate $=\mathrm{k}_{\mathrm{CAT}}^{\mathrm{C}}=\frac{\mathrm{P}_{\mathrm{m}}^{\mathrm{C}}}{\mathrm{RbcL} \mathrm{C}^{-1}}$

Equation 12

255 where $\mathrm{P}_{\mathrm{m}}^{\mathrm{C}}$ is the carbon-specific maximum fixation rate (mol C g C ${ }^{-1} \mathrm{~s}^{-1}$ ) and $\mathrm{RbcL} \mathrm{C}^{-1}(\mathrm{~mol} \mathrm{RbcL}$ $256 \mathrm{~g} \mathrm{C}^{-1}$ ) was estimated from immunoquantitation data normalized to carbon.

Light absorption 
260 A dual beam spectrophotometer (Perkin Elmer, Lambda 850) equipped with an integrating sphere 261 was used to determine the spectral values of the optical density (OD $(\lambda)$ ) of the cultures. Filtered 262 culture medium was used as reference. The chlorophyll $a$-specific absorption coefficient $\left(\mathrm{a}^{*}(\lambda)\right.$ in $263 \mathrm{~m}^{2} \mathrm{mg} \mathrm{Chla} a^{-1}$ ) was calculated as follow:

$265 \mathrm{a}^{*}(\lambda)=\frac{2.3 \cdot \mathrm{OD}(\lambda)}{\mathrm{l} \cdot[\mathrm{Chl} a]}$

\section{Equation 13}

where $l$ is the path length of the cuvette $(0.01 \mathrm{~m})$ and [Chla] the chlorophyll $a$ concentration $(\mathrm{mg}$ $\left.268 \mathrm{~m}^{-3}\right)$.

\section{Statistical tests}

271 To test for differences between light and dark with regard to physiological characteristics we used 272 t-test. Normality was tested by a Shapiro-Wilk test. To test differences between mean growth rates 273 in Experiment 1 performed an ANOVA. Data analyses were performed using the Sigma Plot 12.5. 274 In the figures, asterisks indicate significant differences (one asterisk : $\mathrm{P}<0.05$, two: $\mathrm{P}<0.001$ ) 275 between light and dark acclimated cells. In the results section, statistics are described in detail ( $\mathrm{t}, \mathrm{F}$ 276 df, P). Results of Figure 5 statistics are presented in Online resource 5.

\section{Results}

280 Experiment 1: From darkness to light. We monitored the growth and photochemistry of cultures 281 incubated 1 month in the dark and then exposed to 4 different light cycles (different light level but 282 same duration of the photoperiod, see Online resource 1 and Material and methods section, ). The 283 light cycles roughly mimicked a natural light cycle and allowed a progressive increase in growth 284 irradiance during the first hours after re-illumination. Cells were able to restart growth during the 285 first day after light recovery (Figure 1). At day 7 and later, growth rates began to decrease due to 286 unknown limitations in the 3 highest of the 4 light conditions. We computed the mean growth rates 287 between days 1 and 6 (i.e when growth was not yet limited). The mean growth rates increased with 288 mean growth irradiance between 5 and $41 \mu$ mol photon $\mathrm{m}^{-2} \mathrm{~s}^{-1}$ and then remained constant under 289 higher irradiance (Anova test, $\mathrm{F}_{3}=134.954, \mathrm{P}<0.001$ and see the Pairwise multiple comparison

290 procedure with Holm-Sidak method in Online resource 5). The irradiance-saturated growth rate 
$291\left(0.43 \pm 0.02 \mathrm{~d}^{-1}\right.$ at 41 and $154 \mu \mathrm{mol}$ photon $\left.\mathrm{m}^{-2} \mathrm{~s}^{-1}\right)$ is in the range of light saturated growth rates 292 found in polar species grown at $0^{\circ} \mathrm{C}$ (Sakshaug 2004, Lacour et al. 2017), and slightly lower than 293 C. neogracilis growth rates measured under continuous illumination in semi-continuous culture $294\left(0.6 \mathrm{~d}^{-1}\right.$, unpublished results). Culture growth rates did not seem affected by the dark period after 295 illumination was resumed (Figure 1B). Between 0 and 8 hours, the instantaneous growth rate 296 remained almost null in all the treatments. Growth restarted between 8 and 32 hours after re297 illumination at high rate $\left(0.58 \pm 0.03 \mathrm{~d}^{-1}\right)$ and was not affected by growth irradiance at this early 298 stage. After 32 hours, the instantaneous growth rates were similar to the irradiance-specific mean 299 growth rates.

300

301 The maximum PSII electron transport rate $\left(\mathrm{ETR}_{\mathrm{m}}\right)$ increased during the first hour after re302 illumination in all the conditions (Figure 2A, 3A). This increase was even more pronounced at high 303 irradiance with no apparent damage to PSII even at the highest re-illumination irradiances. The 304 light saturation parameter for photochemistry $\left(\mathrm{E}_{\mathrm{K}}{ }^{\mathrm{ETR}}\right)$ also increased after re-illumination, 305 apparently to acclimate to the new growth conditions (Figure 2B, 3B). The increases were 306 particularly high at high irradiance, with a $75 \%$ increase in $\mathrm{ETR}_{\mathrm{m}}$ and a $124 \%$ increase in $\mathrm{E}_{\mathrm{K}}$ at $307154 \mu \mathrm{mol}$ photon $\mathrm{m}^{-2} \mathrm{~s}^{-1}$ during the first hours of exposure to light. The slope of the ETR versus E 308 curves $\left(\alpha^{\mathrm{ETR}}\right)$ decreased during the first day after re-illumination and then increased and stabilised 309 at a value that was dependent on growth irradiance (Figure 2C, 3C). Our results suggest that after 310 2-3 days, cells were nearly acclimated to growth conditions as photochemical parameters $\left(\alpha^{\text {ETR }}\right.$, 311 ETR $_{m}$ and $E_{K}{ }^{\text {ETR }}$ ) stabilized. Mean $\alpha^{\text {ETR }}$ values (measured between day 3 and 5) decreased with 312 growth irradiance (Figure $2 \mathrm{C}, \mathrm{D}$ ) and mean $\mathrm{ETR}_{\mathrm{m}}$ and $\mathrm{E}_{\mathrm{K}}{ }^{\mathrm{ETR}}$ increased with growth irradiance 313 (Figure 2A, B, D).

315 Experiment 2: Prolonged darkness. We compared the physiological characteristics of cells 316 acclimated to $23 \mu \mathrm{mol}$ photon $\mathrm{m}^{-2} \mathrm{~s}^{-1}$ with cells incubated 1 month in complete darkness. 317 Microscopic observations did not reveal the presence of resting spores. Cells incubated in darkness 318 had a lower cell size (Figure 4A, Paired t test, $t_{4}=19.822, p<0.0001$ ). A fraction of the cells 319 divided once during the first hours of the dark period, which may explain the decrease in the mean 320 cell size. Indeed, the total biovolume of the culture (cell volume x cell number) remained constant 321 throughout the dark period (data not shown). Cell viability was not directly assayed in this study, 
322 so that the proportion of the cells that remained viable at the end of the dark period is unknown.

323 However, the rapid and intense growth after light recovery suggests that most of the cells remained 324 viable.

325

326 We observed slightly higher $\mathrm{Chl} a$ to $\mathrm{C}$ ratio in cells incubated in the dark (Figure 4C, Paired t test, $\left.327 \mathrm{t}_{4}=-2.987, \mathrm{p}=0.04\right)$ and relatively unchanged chlorophyll specific absorption coefficient $\left(\mathrm{a}^{*}\right.$, 328 Online resource 2, Paired t test, $\mathrm{t}_{10}=0.893, \mathrm{p}=0.393$ ) and optical absorption cross section of PSII 329 ( $\sigma^{\mathrm{OPT}}$ PSII, Online resource 3$)$. Cells thus maintained their ability to capture light throughout the dark 330 period. Pigment contents remained unchanged after the dark period with the exception of 331 xanthophylls (Figure 4D). Total xanthophyll was not changed (Paired t test, $t_{4}=-1.386, p=0.238$ ) 332 but the de-epoxidation ratio was dramatically higher in cells incubated in darkness (DES $=58$, 333 Paired $\mathrm{t}$ test, $\mathrm{t}_{4}=-160.045, \mathrm{p}<0.0001$ ). This DES was indeed higher than the DES measured in a 334 previous study on $C$. neogracilis acclimated to very high irradiance (continuous light, $400 \mu \mathrm{mol}$ 335 photon $\mathrm{m}^{-2} \mathrm{~s}^{-1} ; \mathrm{DES}=27$ ). This is an unexpected result because diatoxanthin is generally produced 336 at high irradiances (see discussion). The $\mathrm{C} / \mathrm{N}$ ratio was lower in cells incubated in the dark (Figure $3374 \mathrm{~B}$, Paired $\mathrm{t}$ test, $\mathrm{t}_{4}=2.810, \mathrm{p}=0.048$ ). The Rubisco to carbon ratio was not significantly different 338 between light and dark (Figure 4E, Paired $t$ test, $\mathrm{t}_{3}=-0.218, \mathrm{p}=0.841$ ). Unchanged Rubisco content 339 and decreased photosynthetic capacity (see below) led to a decrease of the apparent catalytic 340 turnover rate of Rubisco $\left(\mathrm{k}_{\text {cat }}^{\mathrm{C}}, \mathrm{C} \mathrm{s}^{-1}\right.$ per site $)$ in darkness.

342 We used incubations at various irradiances to investigate the potential for photochemistry in cells 343 acclimated to the light and to the dark. We used the approach of Hendrickson et al. (2004) to 344 compare the potential fate of absorbed light energy (Figure 5 and materials and methods section). 345 The fraction of absorbed irradiance consumed via photochemistry ( $\left.\Phi_{\mathrm{PSII}}\right)$ was higher in cells 346 acclimated to $23 \mu \mathrm{mol}$ photon $\mathrm{m}^{-2} \mathrm{~s}^{-1}$ across all the incubation irradiances tested (see the results of 347 the statistical tests in Online resource 5). The regulated thermal dissipation $\left(\Phi_{\mathrm{NPQ}}\right)$ was also 348 generally significantly greater in the light than in the dark (see Online resource 5). On the contrary, 349 cells incubated 1 month in the dark showed a much larger fraction of absorbed energy consumed 350 by non-regulated thermal dissipation and fluorescence $\left(\Phi_{\mathrm{f}, \mathrm{D}}\right) . \Phi_{\mathrm{f}, \mathrm{D}}$ is largely dominated by thermal 351 dissipation since fluorescence accounts for only a small fraction of absorbed excitation 352 (Hendrickson et al. 2004). The high de-epoxidation ratio found in the dark may be responsible for 
353 a constitutive NPQ that is measured as non-regulated thermal dissipation since short-term changes 354 in light intensity do not alter its efficiency.

356 Cells incubated in the dark showed significantly lower $\mathrm{F}_{\mathrm{v}} / \mathrm{F}_{\mathrm{m}}$ (Paired $\mathrm{t}$ test, $\mathrm{t}_{3}=27.626, \mathrm{p}=0.0001$ ), $357 \sigma_{\text {PSII }}\left(\right.$ Paired $t$ test, $\left.\mathrm{t}_{3}=14.017, \mathrm{p}=0.0007\right)$ and $\mathrm{F}_{0} /\left(\sigma_{\mathrm{PSII}} \mathrm{Chl} a\right)$ (Paired $\mathrm{t}$ test, $\left.\mathrm{t}_{3}=18.002, \mathrm{p}=0.0004\right)$, 358 a proxy for the content of active PSII (Figure 6A) (Oxborough et al. 2012, Silsbe et al. 2015, 359 Murphy et al. 2017). The PSII ETR versus incubation irradiance curves were highly affected by 360 the dark period (Figure 6B, 6C and Online resource 4). ETR $\mathrm{m}_{\mathrm{m}}$ and $\alpha^{\mathrm{ETR}}$ were both 2.3 fold lower 361 after 1 month in the dark, (Paired $\mathrm{t}$ test, $\mathrm{t}_{10}=9.320, \mathrm{p}<0.0001$ and Paired $\mathrm{t}$ test, $\mathrm{t}_{10}=10.336, \mathrm{p}<$ 3620.0001 respectively), resulting in an unchanged $\mathrm{E}_{\mathrm{K}}{ }^{\mathrm{ETR}}$ (Paired $\mathrm{t}$ test, $\mathrm{t}_{10}=-0.411, \mathrm{p}=0.690$ ).

We obtained carbon fixation rate versus incubation irradiance curves ( $\mathrm{P}$ vs $\mathrm{E}$ curves) for cells 365 incubated 1 month in the dark. We compared the photosynthetic characteristics of cells incubated in the dark with cells acclimated to 3 other continuous growth irradiances $(10,50,80 \mu$ mol photon $\left.\mathrm{m}^{-2} \mathrm{~s}^{-1}\right)$ (see methods, Figure 7). The carbon-specific maximum fixation rate $\left(\mathrm{P}_{\mathrm{m}}^{\mathrm{C}}\right)$ was not affected by growth irradiance (Figure 7A) and was $\sim 9$ times higher than the $\mathrm{P}_{\mathrm{m}}^{\mathrm{C}}$ of cells incubated in the dark for 1 month (Figure 7B, Paired $\mathrm{t}$ test, $\mathrm{t}_{10}=31.516, \mathrm{p}<0.0001$ ). The Chl $a$ specific initial slope of the PI curve $\left(\alpha^{*}\right)$ was also $~ 7$ times higher in the light than in the dark (Figure 7C, Paired t test, $\left.\mathrm{t}_{10}=3.998, \mathrm{p}=0.0025\right)$. The capacity of cells incubated in the dark to fix carbon was thus initially restricted upon re-exposure to both low and high irradiance.

\section{Discussion}

375 Physiology of recovery. The duration of the total darkness is often longer than one month in the 376 Arctic environment. However, most of the physiological acclimatory changes have been shown to 377 occur during the first days of the dark period and cell physiology after one month seems to be 378 therefore representative of the dark acclimation state (Peters and Thomas 1996). 379 Diatoms,particularly polar species are known for their dark survival capabilities (Antia and Cheng 380 1970, Bunt and Lee 1972, Smayda and Mitchell-Innes 1974, Palmisano and Sullivan 1982, 1983, 381 Murphy and Cowles 1997, Fang and Sommer 2017, Kvernvik et al. 2018). However, how they 382 achieve survival and deal with the return to light is unclear. 
384 In order to study light recovery from darkness in C. neogracilis, we used a range of light from 5 to $385154 \mu \mathrm{mol}$ photon ${ }^{-1} \mathrm{~m}^{-2} \mathrm{~s}^{-1}$. We did not observe any time delay before growth resumed in any of the light regimes (Figure 1). Such rapid recovery is not a ubiquitous response in microalgae. For example, the pelagophyte Aureococcus anophagefferens needs more than 20 days to restart growth after 30 days in the dark (Popels and Hutchins 2002). The duration of the lag phase was shown to depend on temperature, on the duration of the dark period and on the growth phase before the dark period and may result from having a significant proportion of the cells being dead (Peters 1996, Peters and Thomas 1996, Popels and Hutchins 2002). In the field, Berge et al. (2015) showed that in Kongsfjorden (Svalbard) during the polar night, primary producers were physiologically active and able to rapidly restart photosynthesis as soon as irradiance reached $0.5 \mu \mathrm{mol}$ photons $\mathrm{m}^{-2} \mathrm{~s}^{-1}$. Our results demonstrate the strong ability of $C$. neogracilis to survive long periods of darkness and a high level of physiological plasticity allowing fast growth recovery upon re-illumination.

Our results show that the light intensity experienced during re-illumination only slightly influence the growth rate recovery. The initial growth recovery was fast and intense, as instantaneous growth rate was $0.58 \mathrm{~d}^{-1}$ between 8 and 32 hours, which corresponds to almost 1 doubling per day. Such a growth rate is similar to the growth rates measured in healthy light-saturated cultures of $C$. neogracilis at $0^{\circ} \mathrm{C}$ (unpublished results) and higher than the mean growth rate of polar species at $0^{\circ} \mathrm{C}\left(0.46 \pm 0.23 \mathrm{~d}^{-1}\right.$, (Lacour et al. 2017)). It also indicates that most of the cells remained viable throughout the dark period. Moreover, the resumption of growth between 8 and 32 hours was also high under re-illumination with only $5 \mu \mathrm{mol}$ photon $\mathrm{m}^{-2} \mathrm{~s}^{-1}$, which is a light-limiting level for longer term growth. This suggests that the growth resumption was not fuelled mainly by photosynthesis but likely by carbon reserves. During the following days, growth stabilized at different rates, which were indeed dependent on light intensity. Such rapid recovery relies largely on the rapid acclimation of its photophysiology. The photochemical properties of the cells rapidly acclimated to the new growth conditions (Figure 2, Figure 3). Kvernvik et al. (2018) also showed rapid 410 increases in the efficiency of photosynthetic electron transport of natural phytoplankton 411 communities upon re-illumination. The immediate and intense increase (within 1 hour) of $E_{K}$ and 412 ETR $_{m}$ suggests a re-organisation of the existing photosystems rather than de novo synthesis of new 413 proteins and pigments (Peters and Thomas 1996, Baldisserotto et al. 2005, Morgan-Kiss et al. 2006, 414 Ferroni et al. 2007, Nymark et al. 2013). It can be explained by light-induced reactivation of 
415 enzymes involved in downstream reactions (Maxwell and Johnson 2000). The relaxation of 416 xanthophyll-related NPQ may also account for such rapid recovery of photochemical capacity. 417 Culture growth rates (computed between days 1 and 6) and photophysiological properties (Figure 418 2D) are comparable to those of this microalgae (unpublished results) and other polar microalgae 419 cultured without previous period of darkness under comparable light intensities (reviewed in 420 Lacour et al. (2017)).. It suggests that prolonged darkness has no impact on Arctic diatom ability 421 to acclimate to new growth conditions.

\section{Dark physiology. How does $\boldsymbol{C}$. neogracilis prepare for rapid growth recovery?}

C. neogracilis cells kept in darkness maintain their capacity to capture light, as shown by the photosynthetic pigments (Figure 4C), the chlorophyll specific absorption coefficient (Online resource 2$)$ and the optical absorption cross section of PSII ( $\sigma^{\mathrm{OPT}}{ }_{\mathrm{PSII}}$, Online resource 3 ) that remained relatively unchanged after one month in the dark, with $\mathrm{a}^{*}(455 \mathrm{~nm})$ and $\sigma^{\mathrm{OPT}}{ }_{\mathrm{PSII}}(455 \mathrm{~nm})$ are $\approx 0.9 \mathrm{X}$ of the levels found in cells acclimated to the light (data not shown). At $12^{\circ} \mathrm{C}, \mathrm{Chl} a$ per Cell in Thalassiosira weissflogii was previously shown to remain constant during 2 months in total darkness (Murphy and Cowles 1997). The benefit to maintaining their light harvesting capacity is probably the ability to resume growth relatively promptly when conditions become favorable uppon re-illumination.

The potential for photochemistry was, however, drastically reduced. We observed decreases in $436 \mathrm{~F}_{\mathrm{v}} / \mathrm{F}_{\mathrm{m}}, \sigma_{\mathrm{PSII}}$ (the effective, rather than the optical, absorption cross section) and consequently in 437 both the light-limited $\left(\alpha_{\mathrm{ETR}}\right)$ and light-saturated $\left(\mathrm{ETR}_{\mathrm{m}}\right)$ activity of PSII. Decreases in the potential 438 for photochemistry were observed in polar diatoms (Wulff et al. 2008, Reeves et al. 2011, Martin 439 et al. 2012) and polar rhodophytes (Lüder et al. 2002) incubated in darkness and were interpreted 440 as a progressive degradation of light-harvesting antennae and/or reaction centres. Nymark et al. 441 (2013) suggested instead that decreases in $\alpha_{\text {ETR }}$ were explained by lower resonance energy transfer 442 efficiency from the light-harvesting antenna pigments to the PSII reaction centre, probably 443 resulting from structural changes within the light-harvesting antenna complexes. Our results 444 suggest that in the case of $C$. neogracilis, the decrease of the potential for photochemistry is a 445 regulated response to prolonged darkness rather than actual PSII damage or dismantlement. Indeed, 
446 this decrease may be at least partially due to an accumulation of Diatoxanthin (35 fold DES 447 increase) that induces sustained heat dissipation and thereby lowers $\sigma_{\text {PSII }}$ even though pigment 448 content and $\sigma^{\mathrm{OPT}}$ PSII are maintained. Some observations in the field (Brunet et al. 2006, Brunet et 449 al. 2007) and in culture (Deventer and Heckman 1996, Jakob et al. 1999, Lavaud et al. 2002) 450 showed that microalgae exposed to darkness exhibit significant levels of chlororespiration. 451 Chlororespiratory energization of the thylakoid membrane maintains a proton gradient, an activated 452 xanthophyll cycle and an ATP synthase in an active state during dark periods, which could be 453 advantageous upon re-exposure to light (Goss and Jakob 2010). This respiratory pathway may also 454 provide energy to sustain metabolic activity and/or balance the ATP:reductant levels in the 455 chloroplast under prolonged darkness. The accumulation of Dt probably keeps $C$. neogracilis cells 456 in a photo-protected, highly dissipative state with a low conversion efficiency of absorbed light 457 into photochemistry and thus a low risk of reactive oxygen dependent damage (Oguchi et al. 2011, 458 Murphy et al. 2017). When light returns, C. neogracilis can relax xanthophyll-related NPQ to 459 optimize light harvesting.

461 The potential for carbon fixation was particularly affected by darkness. Both the light-limited $(\alpha)$ 462 and the light-saturated carbon-specific fixation rates $\left(\mathrm{P}_{\mathrm{m}}^{\mathrm{C}}\right)(20 \mathrm{~min}$ incubations at various 463 irradiances) were drastically lowered in dark conditions, to an even greater degree than the drop in 464 ETR $_{\mathrm{m}}$. Several authors noticed a drop in photosynthetic capacity after several days in darkness 465 (Palmisano and Sullivan 1982, Dehning and Tilzer 1989, Peters and Thomas 1996). Interestingly, 466 the Rubisco protein content was not significantly affected by darkness. Thus, Rubisco protein pool 467 size (Young et al. 2015) is not in this case responsible for the observed decrease in $\mathrm{P}_{\mathrm{m}}^{\mathrm{C}}$ as illustrated 468 by the reduced apparent catalytic turnover rate of Rubisco in darkness. However, a regulated 469 decrease in Rubisco activity could account for the decline in $\mathrm{P}_{\mathrm{m}}^{\mathrm{C}}$. In fact, MacIntyre et al. (1997) 470 showed thatdeactivation of the carbon assimilating machinery (e.g., RuBisCO) occur very rapidly 471 in light-dark transitions in the chlorophyte Dunaliella tertiolecta and especially in the diatom 472 Thalassiosira pseudonana (timescale: minute). The maintenance of the Rubisco pool size probably 473 contributes to the rapid recovery through re-activation when light returns.

475 The discrepancy between the 2.3 fold dark decrease in ETR $\mathrm{m}_{\mathrm{m}}$ versus the 9 fold dark decrease of $476 \quad \mathrm{P}_{\mathrm{m}}^{\mathrm{C}}$ shows that during prolonged darkness carbon fixation potential is down regulated more than 
477 photochemistry potential per PSII. We used a proxy of the amount of active PSII per Chl $a$ 478 (Oxborough et al. 2012, Silsbe et al. 2015, Murphy et al. 2016) to understand if the number of active PSII can help to reconcile carbon fixation and photochemistry. The number of active PSII 480 indeed decreased significantly by 1.5 fold in the dark but cannot fully account for the discrepancy 481 between a predicted $2.3 \times 1.5=3.5$ fold decrease in the potential for electron transport and the 9 482 fold decrease in the potential for carbon fixation. This suggests that electrons produced at PSII are 483 diverted away from carbon fixation when cells acclimated to prolonged darkness are re484 illuminated. Schuback et al. (2017) had similar observations in Arctic field populations, 485 particularly in assemblages exposed to short-term super-saturating irradiances. They also suggested 486 that it could be related to an up-regulation of alternative electron pathways. Laboratory (Wagner et 487 al. 2006, Bailey et al. 2008, Cardol et al. 2008) and field studies (Mackey et al. 2008, Grossman et 488 al. 2010, Schuback et al. 2015, Schuback et al. 2017, Zhu et al. 2017, Hughes et al. 2018b) have 489 examined the processes that uncouple rates of $\mathrm{CO}_{2}$ assimilation and photosynthetic electron 490 transport. Those pathways are generally active under high irradiance or under severe nutrient 491 limitation, when cells are subjected to metabolic unbalance (see also the review by Hughes et al. 492 (2018a)). After one month under complete darkness, some downstream photosynthetic processes 493 are probably constrained, generating such metabolic unbalance. Alternative electron pathways may 494 create an electron valve on the acceptor side of PSII and thus protect the system from photodamage 495 by lowering the redox pressure until carbon assimilation can be re-activated. Again, upon light 496 recovery, those alternative electron flows can be rapidly redirected to carbon fixation in order to 497 fuel growth.

\section{Conclusion}

500

501 Polar microalgae live under extreme environmental conditions: permanently low temperatures, 502 extreme variations in irradiance and above all, long period of complete darkness. The ability to 503 survive such periods of darkness and to re-initiate growth when light returns affects the fitness of 504 a phytoplankton species in this environment. This study illustrates how the Arctic diatom $C$. 505 neogracilis is able to withstand long periods of darkness and sudden light bursts of variable 506 intensity. The capacity to recover safely and rapidly relies on the maintenance, through the dark 507 period, of the main components of the photosynthetic machinery (PSII and pigments, Rubisco). 
508

509

510

511 512 investigation.

513

514

515

516

517

518

519

520

521

522

523

524

525

526

527

528

529

530

531

532

533

534

535

536

537

538

539

540

541

542

543

544

545

546

547

548

\section{References}

The flexibility of $C$. neogracilis probably relies on the induction of xanthophyll-related NPQ and possible induction of alternate electron pathways. The extremely low expenditures of energy during darkness - suggested by undetectable organic carbon consumption during one month in darknessis one extremely important aspect that was not directly studied in this work and needs further

\section{Compliance with Ethical Standards}

The authors declare that they have no conflict of interest.

Antia NJ, Cheng JY 1970. The survival of axenic cultures of marine planktonic algae from prolonged exposure to darkness at $20^{\circ} \mathrm{C}$. Phycologia 9:179-183.

Arrigo KR, Mills MM, Kropuenske LR, van Dijken GL, Alderkamp A-C, Robinson DH 2010. Photophysiology in two major southern ocean phytoplankton taxa: photosynthesis and growth of Phaeocystis antarctica and Fragilariopsis cylindrus under different irradiance levels. Integr. Comp. Biol. 50:950-966.

Bailey S, Melis A, Mackey KRM, Cardol P, Finazzi G, van Dijken G, Berg GM, Arrigo K, Shrager J, Grossman A 2008. Alternative photosynthetic electron flow to oxygen in marine Synechococcus. Biochimica et Biophysica Acta (BBA) - Bioenergetics 1777:269-276.

Baldisserotto C, Ferroni L, Andreoli C, Fasulo MP, Bonora A, Pancaldi S 2005. Darkacclimation of the chloroplast in Koliella antarctica exposed to a simulated austral night condition. Arct. Antarct. Alp. Res. 37:146-156.

Balzano S, Gourvil P, Siano R, Chanoine M, Marie D, Lessard S, Sarno D, Vaulot D 2012. Diversity of cultured photosynthetic flagellates in the northeast Pacific and Arctic Oceans in summer. Biogeosciences 9:4553-4571.

Balzano S, Percopo I, Siano R, Gourvil P, Chanoine M, Marie D, Vaulot D, Sarno D 2017. Morphological and genetic diversity of Beaufort Sea diatoms with high contributions from the Chaetoceros neogracilis species complex. J. Phycol. 53:161-187.

Berge J, Daase M, Renaud Paul E, Ambrose William G, Jr., Darnis G, Last Kim S, Leu E, Cohen Jonathan H, Johnsen G, Moline Mark A, Cottier F, Varpe Ø, Shunatova N, Bałazy P, Morata N, Massabuau J-C, Falk-Petersen S, Kosobokova K, Hoppe Clara JM, Węsławski Jan M, Kukliński P, Legeżyńska J, Nikishina D, Cusa M, Kędra M, Włodarska-Kowalczuk M, Vogedes D, Camus L, Tran D, Michaud E, Gabrielsen Tove M, Granovitch A, Gonchar A, Krapp R, Callesen Trine A 2015. Unexpected Levels of Biological Activity during the Polar Night Offer New Perspectives on a Warming Arctic. Curr. Biol. 25:2555-2561. 
549

550

551

552

553

554

555

556

557

558

559

560

561

562

563

564

565

566

567

568

569

570

571

572

573

574

575

576

577

578

579

580

581

582

583

584

585

586

587

588

589

590

591

592

593

594
Brunet C, Casotti R, Vantrepotte V, Conversano F 2007. Vertical variability and diel dynamics of picophytoplankton in the Strait of Sicily, Mediterranean Sea, in summer. Mar. Ecol. Prog. Ser. 346:15-26.

Brunet C, Casotti R, Vantrepotte V, Corato F, Conversano F 2006. Picophytoplankton diversity and photoacclimation in the Strait of Sicily (Mediterranean Sea) in summer. I. Mesoscale variations. Aquat. Microb. Ecol. 44:127-141.

Bunt JS, Lee CC 1972. Data on the Composition and Dark Survival of Four Sea-Ice Microalgae. Limnol. Oceanogr. 17:458-461.

Cardol P, Bailleul B, Rappaport F, Derelle E, Béal D, Breyton C, Bailey S, Wollman FA, Grossman A, Moreau H, Finazzi G 2008. An original adaptation of photosynthesis in the marine green alga Ostreococcus. Proceedings of the National Academy of Sciences 105:78817886.

Dehning I, Tilzer MM 1989. Survival of Scenedesmus acuminatus (chlorophyceae) in darkness. J. Phycol. 25:509-515.

Deventer B, Heckman C 1996. Effects of prolonged darkness on the relative pigment content of cultured diatoms and green algae. Aquatic Science 58:241-252.

Fang X, Sommer U 2017. Overwintering effects on the spring bloom dynamics of phytoplankton. J. Plankton Res. 39:772-780.

Ferroni L, Baldisserotto C, Zennaro V, Soldani C, Fasulo MP, Pancaldi S 2007. Acclimation to darkness in the marine chlorophyte Koliella antarctica cultured under low salinity: hypotheses on its origin in the polar environment. Eur. J. Phycol. 42:91-104.

Genty B, Briantais J-M, Baker NR 1989. The relationship between the quantum yield of photosynthetic electron transport and quenching of chlorophyll fluorescence. Biochimica et Biophysica Acta (BBA) - General Subjects 990:87-92.

Goss R, Jakob T 2010. Regulation and function of xanthophyll cycle-dependent photoprotection in algae. Photosynth. Res. 106:103-122.

Grossman AR, Mackey KRM, Bailey S 2010. A perpective on photosynthesis in the oligotrophic oceans: hypothesis concerning alternate routes of electron flow. J. Phycol. 46:629-634.

Guillard RRL 1975. Culture of phytoplankton for feeding marine invertebrates. In W. L. S. a. M. H. C. (Eds) Culture of invertabrate animals, N.Y.:29-66.

Hancke K, Lund-Hansen LC, Lamare ML, Højlund Pedersen S, King MD, Andersen P, Sorrell BK 2018. Extreme Low Light Requirement for Algae Growth Underneath Sea Ice: A Case Study From Station Nord, NE Greenland. Journal of Geophysical Research: Oceans 123:985-1000. 
595

596

597

598

599

600

601

602

603

604

605

606

607

608

609

610

611

612

613

614

615

616

617

618

619

620

621

622

623

624

625

626

627

628

629

630

631

632

633

634

635

636

637

638

639

640
Hendrickson L, Furbank R, Chow W 2004. A simple alternative approach to assessing the fate of absorbed light energy using chlorophyll fluorescence. Photosynth. Res. 82:73-81.

Hughes DJ, Campbell DA, Doblin MA, Kromkamp JC, Lawrenz E, Moore CM, Oxborough K, Prášil O, Ralph PJ, Alvarez MF, Suggett DJ 2018a. Roadmaps and Detours: Active Chlorophylla Assessments of Primary Productivity Across Marine and Freshwater Systems. Environ. Sci. Technol. 52:12039-12054.

Hughes DJ, Varkey D, Doblin MA, Ingleton T, McInnes A, Ralph PJ, van Dongen-Vogels V, Suggett DJ 2018b. Impact of nitrogen availability upon the electron requirement for carbon fixation in Australian coastal phytoplankton communities. Limnol. Oceanogr. 63:1891-1910.

Huot Y, Babin M 2010. Overview of Fluorescence Protocols: Theory, Basic Concepts, and Practice. In D. J. Suggett, O. Prášil and M. A. Borowitzka Chlorophyll a Fluorescence in Aquatic Sciences: Methods and Applications. Springer Netherlands. 4:31-74.

Jakob T, Goss R, Wilhelm C 1999. Activation of Diadinoxanthin De-Epoxidase Due to a Chiororespiratory Proton Gradient in the Dark in the Diatom Phaeodactylum tricornutum. Plant Biology 1:76-82.

Kropuenske LR, Mills MM, van Dijken GL, Alderkamp A-C, Mine Berg G, Robinson DH, Welschmeyer NA, Arrigo KR 2010. Strategies and rates of photoacclimation in two major southern ocean phytoplankton taxa: Phaeocystis antarctica (Haptophyta) and Fragilariopsis cylindrus (Bacillariophyceae). J. Phycol. 46:1138-1151.

Kropuenske LR, Mills MM, Van Dijken GL, Bailey S, Robinson DH, Welschmeyer NA, Arrigo KR 2009. Photophysiology in two major Southern Ocean phytoplankton taxa: Photoprotection in Phaeocystis antarctica and Fragilariopsis cylindrus. 54:21.

Kvernvik AC, Hoppe CJM, Lawrenz E, Prášil O, Greenacre M, Wiktor JM, Leu E 2018. Fast reactivation of photosynthesis in arctic phytoplankton during the polar night1. J. Phycol. 54:461-470.

Lacour T, Larivière J, Babin M 2017. Growth, Chl $a$ content, photosynthesis, and elemental composition in polar and temperate microalgae. Limnol. Oceanogr. 62:43-58.

Lacour T, Larivière J, Ferland J, Bruyant F, Lavaud J, Babin M 2018. The Role of Sustained Photoprotective Non-photochemical Quenching in Low Temperature and High Light Acclimation in the Bloom-Forming Arctic Diatom Thalassiosira gravida. Frontiers in Marine Science 5.

Lavaud J, Strzepek RF, Kroth PG 2007. Photoprotection capacity differs among diatoms: Possible consequences on the spatial distribution of diatoms related to fluctuations in the underwater light climate. Limnol. Oceanogr. 52:1188-1194. 
641 Lavaud J, van Gorkom HJ, Etienne AL 2002. Photosystem II electron transfer cycle and

642

643

644

645

646

647

648

649

650

651

652

653

654

655

656

657

658

659

660

661

662

663

664

665

666

667

668

669

670

671

672

673

674

675

676

677

678

679

680

681

682

683

684

685

686 chlororespiration in planktonic diatoms. Photosynth. Res. 74:51-59.

Leu E, Mundy CJ, Assmy P, Campbell K, Gabrielsen TM, Gosselin M, Juul-Pedersen T, Gradinger R 2015. Arctic spring awakening - Steering principles behind the phenology of vernal ice algal blooms. Prog. Oceanogr. 139:151-170.

Lewis MR, Smith JC 1983. A small volume, short-incubation-time method for measure-ment of photosynthesis as a function of incident irradiance. Mar. Ecol.-Prog. Ser. 13:99-102.

Lüder UH, Wiencke C, Knoetzel J 2002. Acclimation of photosynthesis and pigments during and after six months of darkness in Palmaria decipiens (rhodophyta): a study to simulate antarctic winter sea ice cover. J. Phycol. 38:904-913.

Lundholm N, Ribeiro S, Andersen TJ, Koch T, Godhe A, Ekelund F, Ellegaard M 2011. Buried alive - germination of up to a century-old marine protist resting stages. Phycologia 50:629640 .

MacIntyre HL, Cullen JJ 2005. Using cultures to investigate the physiological ecology of microalgae. In R. A. Anderson Algal Culturing Techniques. Academic Press:287-326

MacIntyre HL, Sharkey TD, Geider RJ 1997. Activation and deactivation of ribulose-1,5bisphosphate carboxylase/oxygenase (Rubisco) in three marine microalgae. Photosynth. Res. 51:93-106.

Mackey KRM, Paytan A, Grossman AR, Bailey S 2008. A photosynthetic strategy for coping in a high-light, low-nutrient environment. Limnol. Oceanogr. 53:14.

Martin A, McMinn A, Heath M, Hegseth EN, Ryan KG 2012. The physiological response to increased temperature in over-wintering sea ice algae and phytoplankton in McMurdo Sound, Antarctica and Tromso Sound, Norway. J. Exp. Mar. Biol. Ecol. 428:57-66.

Maxwell K, Johnson GN 2000. Chlorophyll fluorescence-a practical guide. J. Exp. Bot. 51:659668.

McMinn A, Ashworth C, Ryan K 1999. Growth and productivity of Antarctic sea ice algae under PAR and UV irradiances. Bot. Mar. 42:401-407.

McMinn A, Martin A 2013. Dark survival in a warming world. Proceedings of the Royal Society B: Biological Sciences 280:20122909.

Mills MM, Kropuenske LR, van Dijken GL, Alderkamp A-C, Berg GM, Robinson DH, Welschmeyer NA, Arrigo KR 2010. Photophysiology in two southern ocean phytoplankton taxa: photosynthesis of Phaeocystis antarctica (Prymnesiophyceae) and Fragilariopsis cylindrus (Bacillariophyceae) under simulated mixed-layer irradiance. J. Phycol. 46:11141127. 
687

688

689

690

691

692

693

694

695

696

697

698

699

700

701

702

703

704

705

706

707

708

709

710

711

712

713

714

715

716

717

718

719

720

721

722

723

724

725

726

727

728

729

730

731

732
Morgan-Kiss RM, Priscu JC, Pocock T, Gudynaite-Savitch L, Huner NPA 2006. Adaptation and Acclimation of Photosynthetic Microorganisms to Permanently Cold Environments. Microbiol. Mol. Biol. Rev. 70:222-252.

Mundy CJ, Gosselin M, Ehn J, Gratton Y, Rossnagel A, Barber DG, Martin J, Tremblay J-É, Palmer M, Arrigo KR, Darnis G, Fortier L, Else B, Papakyriakou T 2009. Contribution of under-ice primary production to an ice-edge upwelling phytoplankton bloom in the Canadian Beaufort Sea. Geophysical Research Letters 36:L17601.

Murphy AM, Cowles TJ 1997. Effects of darkness on multi-excitation in vivo fluorescence and survival in a marine diatom. Limnol. Oceanogr. 42:1444-1453.

Murphy CD, Ni G, Li G, Barnett A, Xu K, Grant-Burt J, Liefer JD, Suggett DJ, Campbell DA 2016. Quantitating active photosystem II reaction center content from fluorescence induction transients. Limnology and Oceanography: Methods 15:54-69.

Murphy CD, Roodvoets MS, Austen EJ, Dolan A, Barnett A, Campbell DA 2017. Photoinactivation of Photosystem II in Prochlorococcus and Synechococcus. PLoS ONE 12:e0168991.

Nymark M, Valle KC, Hancke K, Winge P, Andresen K, Johnsen G, Bones AM, Brembu T 2013. Molecular and Photosynthetic Responses to Prolonged Darkness and Subsequent Acclimation to Re-Illumination in the Diatom Phaeodactylum tricornutum. PLoS ONE 8:e58722.

Oguchi R, Terashima I, Kou J, Chow WS 2011. Operation of dual mechanisms that both lead to photoinactivation of Photosystem II in leaves by visible light. Physiol. Plant 142:47-55.

Oxborough K, Moore CM, Suggett DJ, Lawson T, Chan HG, Geider RJ 2012. Direct estimation of functional PSII reaction center concentration and PSII electron flux on a volume basis: a new approach to the analysis of Fast Repetition Rate fluorometry (FRRf) data. Limnology and Oceanography: Methods 10:142-154.

Palmisano AC, Sullivan CW 1982. Physiology of sea ice diatoms. I. response of three polar diatoms to a simulated summer-winter transition. J. Phycol. 18:489-498.

Palmisano AC, Sullivan CW 1983. Physiology of sea ice diatoms. II. Dark survival of three polar diatoms. Can. J. Microbiol. 29:157-160.

Parsons TR, Maita Y, Lalli CM 1984. 5.1 - Photosynthesis as Measured by the Uptake of Radioactive Carbon. In T. R. P. M. M. Lalli A Manual of Chemical \& Biological Methods for Seawater Analysis. Pergamon, Amsterdam:115-120.

Peters E 1996. Prolonged darkness and diatom mortality .2. Marine temperate species. J. Exp. Mar. Biol. Ecol. 207:43-58. 
733

734

735

736

737

738

739

740

741

742

743

744

745

746

747

748

749

750

751

752

753

754

755

756

757

758

759

760

761

762

763

764

765

766

767

768

769

770

771

772

773

774

775

776

777

778
Peters E, Thomas DN 1996. Prolonged darkness and diatom mortality I: Marine Antarctic species. J. Exp. Mar. Biol. Ecol. 207:25-41.

Petrou K, Doblin M, Ralph P 2011. Heterogeneity in the photoprotective capacity of three Antarctic diatoms during short-term changes in salinity and temperature. Mar. Biol. 158:1029-1041.

Petrou K, Hill R, Brown CM, Campbell DA, Doblin MA, Ralph PJ 2010. Rapid photoprotection in sea-ice diatoms from the East Antarctic pack ice. Limnol. Oceanogr. 55:8.

Petrou K, Kranz SA, Trimborn S, Hassler CS, Ameijeiras SB, Sackett O, Ralph PJ, Davidson AT 2016. Southern Ocean phytoplankton physiology in a changing climate. J. Plant Physiol. 203:135-150.

Petrou K, Ralph P 2011. Photosynthesis and net primary productivity in three Antarctic diatoms: possible significance for their distribution in the Antarctic marine ecosystem. Mar. Ecol. Prog. Ser. 437:27-40.

Platt T, Gallegos CL, Harrison WG 1980. Photoinhibition of photosynthesis in natural assemblages of marine phytoplankton. J. Mar. Res. 38:687-701.

Popels LC, Hutchins DA 2002. Factors affecting dark survival of the brown tide alga Aureococcus anophagefferens (Pelagophyceae). J. Phycol. 38:738-744.

Poulin M, Daugbjerg N, Gradinger R, Ilyash L, Ratkova T, von Quillfeldt C 2011. The pan-Arctic biodiversity of marine pelagic and sea-ice unicellular eukaryotes: a first-attempt assessment. Mar. Biod. 41:13-28.

Reeves S, McMinn A, Martin A 2011. The effect of prolonged darkness on the growth, recovery and survival of Antarctic sea ice diatoms. Polar Biol. 34:1019-1032.

Rivkin RB, Putt M 1987. Heterotrophy and photoheterotrophy by antarctic microalgae - lightdependent incorporation of amino-acids and glucose. J. Phycol. 23:442-452.

Sakshaug E 2004. Primary and secondary production in Arctic seas. In E. R. Stein and R.W.Macdonald The Organic Carbon Cycle in the Arctic Ocean. Springer, Berlin:57-81.

Schaub I, Wagner H, Graeve M, Karsten U 2017. Effects of prolonged darkness and temperature on the lipid metabolism in the benthic diatom Navicula perminuta from the Arctic Adventfjorden, Svalbard. Polar Biol. 40:1425-1439.

Schuback N, Hoppe CJM, Tremblay J-É, Maldonado MT, Tortell PD 2017. Primary productivity and the coupling of photosynthetic electron transport and carbon fixation in the Arctic Ocean. Limnol. Oceanogr. 62:898-921. 
779

780

781

782

783

784

785

786

787

788

789

790

791

792

793

794

795

796

797

798

799

800

801

802

803

804

805

806

807

808

809

810

811

812

813

814

815

816

817

818

819

820

821

822

823
Schuback N, Schallenberg C, Duckham C, Maldonado MT, Tortell PD 2015. Interacting Effects of Light and Iron Availability on the Coupling of Photosynthetic Electron Transport and CO2Assimilation in Marine Phytoplankton. PLoS ONE 10:e0133235.

Silsbe GM, Oxborough K, Suggett DJ, Forster RM, Ihnken S, Komárek O, Lawrenz E, Prášil O, Röttgers R, Šicner M, Simis SGH, Van Dijk MA, Kromkamp JC 2015. Toward autonomous measurements of photosynthetic electron transport rates: An evaluation of active fluorescence-based measurements of photochemistry. Limnology and Oceanography: Methods 13:138-155.

Smayda TJ, Mitchell-Innes B 1974. Dark survival of autotrophic, planktonic marine diatoms. Mar. Biol. 25:195-202.

Smith AE, Morris I 1980. Pathways of carbon assimilation in phytoplankton from the antarctic ocean. Limnol. Oceanogr. 25:865-872.

Suggett D, Moore CM, Geider R 2010. Estimating Aquatic Productivity from Active Fluorescence Measurements. In D. J. Suggett, O. Prášil and M. A. Borowitzka Chlorophyll a Fluorescence in Aquatic Sciences: Methods and Applications. Springer Netherlands. 4:103-127.

Thomas SL, Campbell DA 2013. Photophysiology of Bolidomonas pacifica. J. Plankton Res. 35:260-269.

van de Poll WHV, Lagunas M, de Vries T, Visser RJW, Buma AGJ 2011. Non-photochemical quenching of chlorophyll fluorescence and xanthophyll cycle responses after excess PAR and UVR in Chaetoceros brevis, Phaeocystis antarctica and coastal Antarctic phytoplankton. Mar. Ecol.-Prog. Ser. 426:119-131.

Wagner H, Jakob T, Wilhelm C 2006. Balancing the energy flow from captured light to biomass under fluctuating light conditions. New Phytol. 169:95-108.

White AW 1974. Growth of two facultatively heterotrophic marine centric diatoms. J. Phycol. 10:292-300.

Wu Y, Jeans J, Suggett D, Finkel Z, Campbell DA 2014. Large centric diatoms allocate more cellular nitrogen to photosynthesis to counter slower RUBISCO turnover rates. Frontiers in Marine Science 1:1-11.

Wulff A, Roleda MY, Zacher K, Wiencke C 2008. Exposure to sudden light burst after prolonged darkness - a case study on benthic diatoms in antarctica. Diatom. Res. 23:519-532.

Young JN, Goldman JAL, Kranz SA, Tortell PD, Morel FMM 2015. Slow carboxylation of Rubisco constrains the rate of carbon fixation during Antarctic phytoplankton blooms. New Phytol. 205:172-181. 
824 Zapata M, Rodriguez F, Garrido JL 2000. Separation of chlorophylls and carotenoids from 825 marine phytoplankton: a new HPLC method using a reversed phase C8 column and pyridine826 containing mobile phases. Mar. Ecol. Prog. Ser. 195:29-45.

827

828 Zhu Y, Ishizaka J, Tripathy SC, Wang S, Sukigara C, Goes J, Matsuno T, Suggett DJ 2017. 829 Relationship between light, community composition and the electron requirement for carbon 830 fixation in natural phytoplankton. Mar. Ecol. Prog. Ser. 580:83-100.

831

832 
833

834

835

836

837

838

839

840

841

842

843

844

845

846

847

848

849

850

851

852

853

854

855

856

857

858

859

860

861

862

863

864

\section{Figure1_Lacour et al.}

Figure 1: Changes in cell density of Chaetoceros neogracilis cultures exposed to 4 different light cycles after 1 month in total darkness at $0^{\circ} \mathrm{C}(\mathrm{A})$. Mean growth rates of triplicate cultures computed between days 1 and 6 are indicated on the graph. Note that mean growth rates were equal in cells exposed to 41 and $154 \mu$ mol photon $\mathrm{m}^{-2} \mathrm{~s}^{-1}$. Each data point is the mean $\pm \mathrm{SD}$ of the 3 different cultures. Instantaneous growth rates of $C$. neogracilis measured during the first eight hours, between eight and 32 hours and between 32 and 54 hours under different light cycles after 1 month in darkness (B). Each bar is the mean $\pm \mathrm{SD}$ of the 3 different cultures.

\section{Figure2_Lacour et al.}

Figure 2: Changes in photochemical properties of Chaetoceros neogracilis at 4 different light cycles after 1 month in total darkness at $0^{\circ} \mathrm{C}$. $\operatorname{ETR}_{m}(A), E_{K}{ }^{E T R}(B), \alpha^{\mathrm{ETR}}(\mathrm{C})$ as a function of time under different light cycles. In $\mathrm{A}, \mathrm{B}, \mathrm{C}$ each data point is the mean $\pm \mathrm{SD}$ of triplicate cultures. Relationship between mean growth irradiance and mean $\mathrm{ETR}_{\mathrm{m}}, \mathrm{E}_{\mathrm{K}}{ }^{\mathrm{ETR}}$ and $\alpha^{\mathrm{ETR}}(\mathrm{D})$. In $\mathrm{D}$, each data point is the mean $\pm \mathrm{SD}$ of 3 consecutive days (day 3, 4 and 5) from triplicate cultures.

\section{Figure3_Lacour et al.}

Figure 3: Enlargement of part of Figure 2. $\operatorname{ETR}_{m}(A), E_{K}^{E T R}(B), \alpha^{E T R}(C)$ as a function of time under different light cycles. In $\mathrm{A}, \mathrm{B}, \mathrm{C}$ each data point is the mean $\pm \mathrm{SD}$ of triplicate cultures.

\section{Figure4_Lacour et al.}

Figure 4: Biochemical characteristics of cells acclimated to $23 \mu \mathrm{mol}$ photon $\mathrm{m}^{-2} \mathrm{~s}^{-1}$ or to the dark. Cell diameter (A), ClN (B), Chl $a / \mathrm{C}(\mathrm{C}),(\mathrm{Dd}+\mathrm{Dt}) / \mathrm{Chl} a, \mathrm{DES}(\mathrm{DES}=\mathrm{Dt} /(\mathrm{Dd}+\mathrm{Dt})), \mathrm{Dt} / \mathrm{Chl} a$ and $\beta$-carotene/Chl $a(\mathrm{D})$, Rubisco to carbon ratio and apparent Rubisco catalytic turnover rate $\left(\mathrm{s}^{-1}\right)(\mathrm{E})$ in cultures acclimated to $23 \mu \mathrm{mol}$ photon $\mathrm{m}^{-2} \mathrm{~s}^{-1}$ (white bars) and after 1 month in the dark (black bars). Each bar is the mean of 3 different cultures. Error bars represent standard deviations. Asterisks indicate significant differences (one asterisk : $\mathrm{P}<0.05$, two: $\mathrm{P}<0.001$ ) between light and dark acclimated cells. 


\section{Figure5_Lacour et al.}

868 Figure 5: Estimated fraction of absorbed irradiance consumed via photochemistry ( $\Phi_{\text {PSII }}$ ), 869 regulated thermal dissipation $\left(\Phi_{\mathrm{NPQ}}\right)$ and non-regulated thermal dissipation and fluorescence $\left(\Phi_{\mathrm{f}, \mathrm{D}}\right)$ 870 as a function of incubation irradiance for cultures of Chaetoceros neogracilis acclimated to 23 $871 \mu \mathrm{mol}$ photon $\mathrm{m}^{-2} \mathrm{~s}^{-1}(\mathrm{~A})$ and incubated one month in the dark (B). Those parameters were defined 872 by Hendrickson et al. (2004) to compare the fate of absorbed light. Each point is the mean of 3 873 different cultures. Error bars represent standard deviations.

874

\section{Figure6_Lacour et al.}

876

877 Figure 6: PSII activity in the light and in the dark. $F_{v} / F_{m}$, $\sigma_{P S I I}$ and proxy for PSII content $F_{O} /$ $878\left(\sigma_{\mathrm{PSII}} \mathrm{Chl} a\right)(\mathrm{A}), \mathrm{ETR}_{\mathrm{m}}$ and $\mathrm{E}_{\mathrm{K}}^{\mathrm{ETR}}(\mathrm{B}), \alpha^{\mathrm{ETR}}(\mathrm{C})$ in cultures acclimated to $23 \mu \mathrm{mol}$ photon $\mathrm{m}^{-2} \mathrm{~s}^{-1}$ 879 (white bars) and after 1 month in the dark (black bars). Each bar is the mean of 3 different cultures. 880 Error bars represent standard deviations. Asterisks indicate significant differences (one asterisk : $881 \mathrm{P}<0.05$, two: $\mathrm{P}<0.001)$ between light and dark acclimated cells.

882

\section{Figure7_Lacour et al.}

885 Figure 7: Carbon specific fixation rate versus incubation irradiance curves of cells incubated in 886 the dark for one month or acclimated to 10,50 and $80 \mu \mathrm{mol}$ photon $\mathrm{m}^{-2} \mathrm{~s}^{-1}$ (minimum of 10 887 generations, see methods) (A). Each data point is the mean of measures from 3 different cultures. 888 Error bars represent standard deviations. $\alpha^{*}(\mathrm{~B})$ and $\mathrm{P}_{\mathrm{m}}^{\mathrm{C}}(\mathrm{C})$ of cell incubated in the dark (black 889 bars, mean \pm SD of triplicate cultures incubated 1 month in the dark) or pooled determinations for 890 cultures acclimated to light (white bars, mean \pm SD of pooled determinations from 10, 50 and 80 $891 \mu \mathrm{mol}$ photon $\mathrm{m}^{-2} \mathrm{~s}^{-1}$ ). Asterisks indicate significant differences (one asterisk: $\mathrm{P}<0.05$, two: $892 \mathrm{P}<0.001)$ between light and dark acclimated cells. 

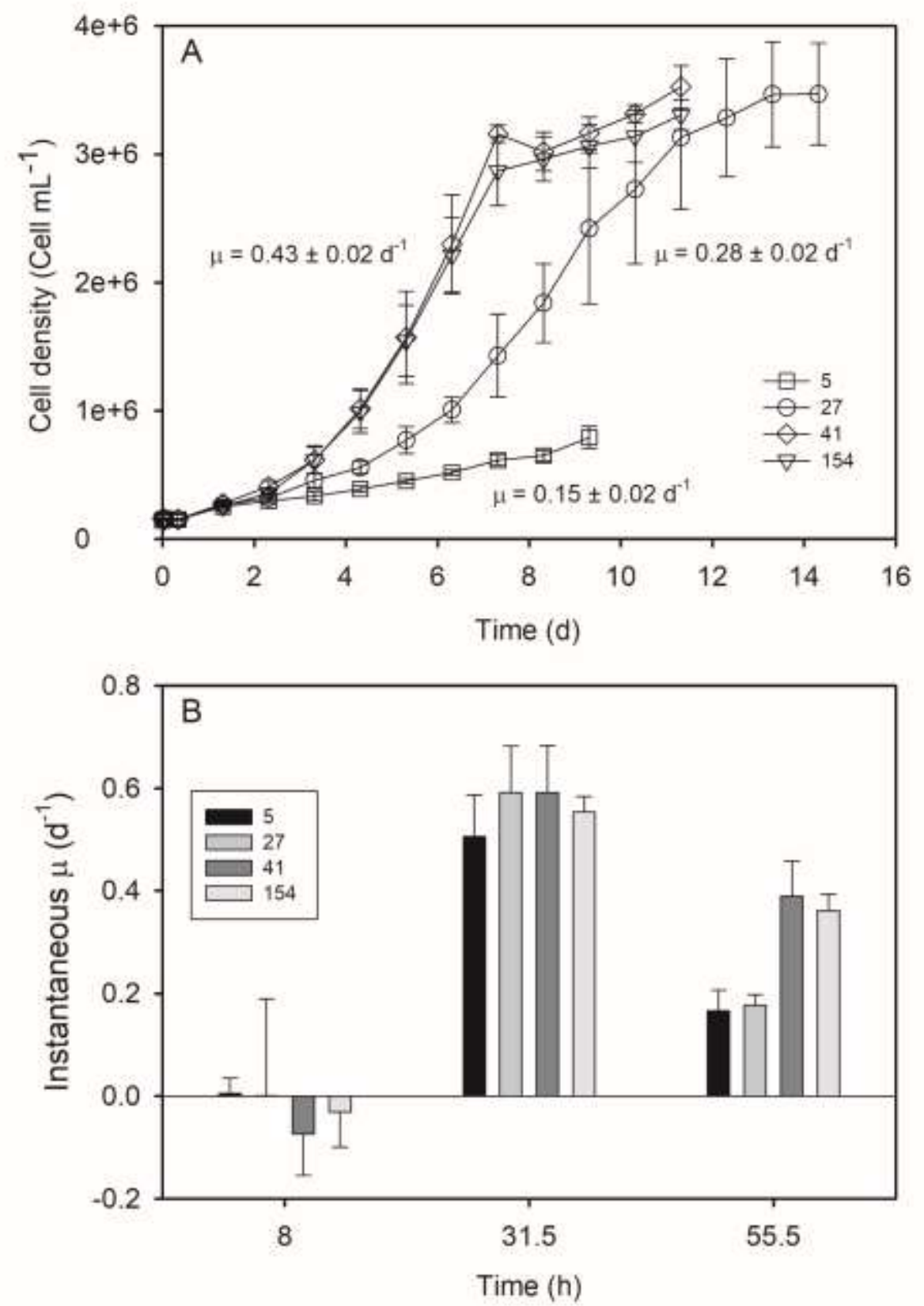

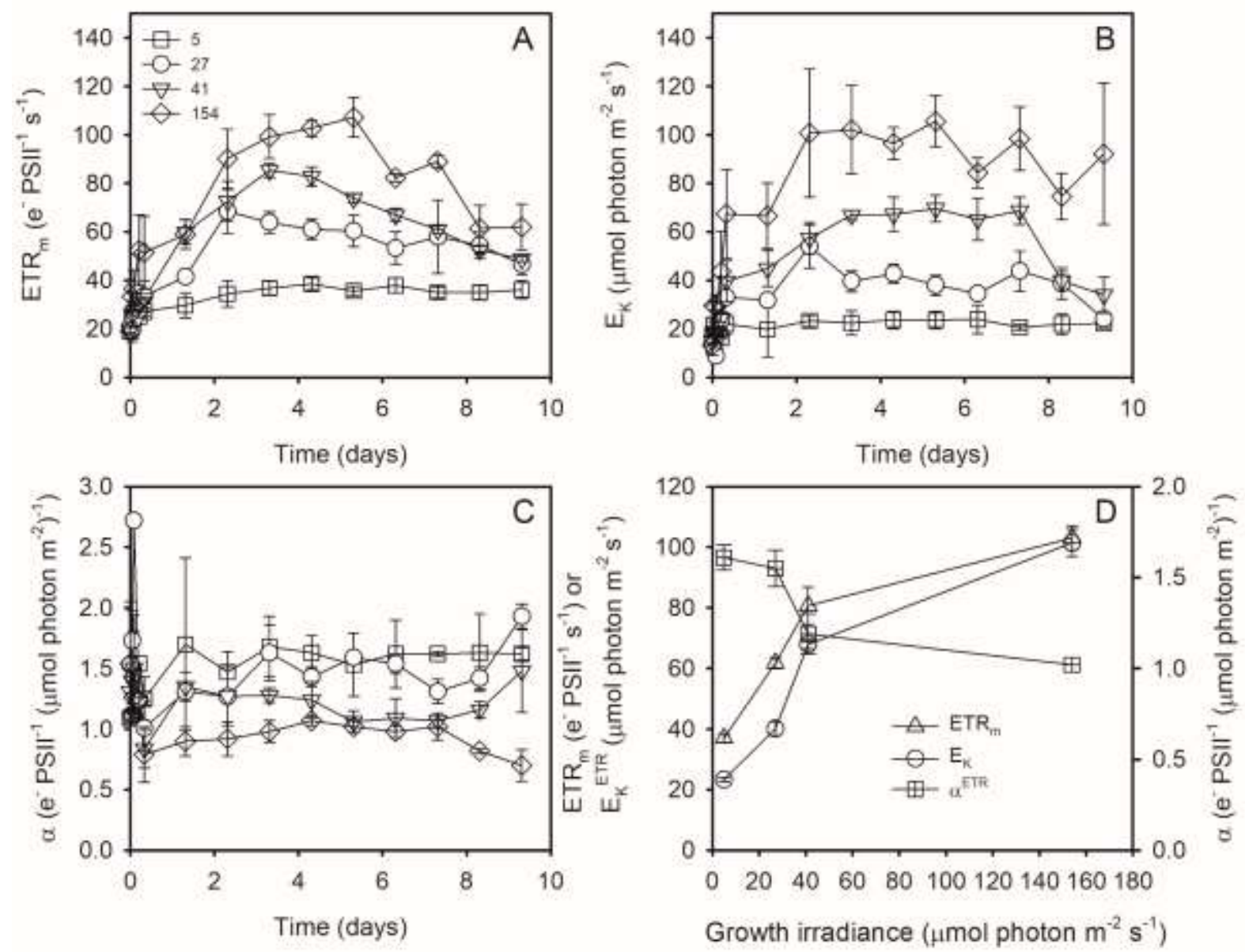

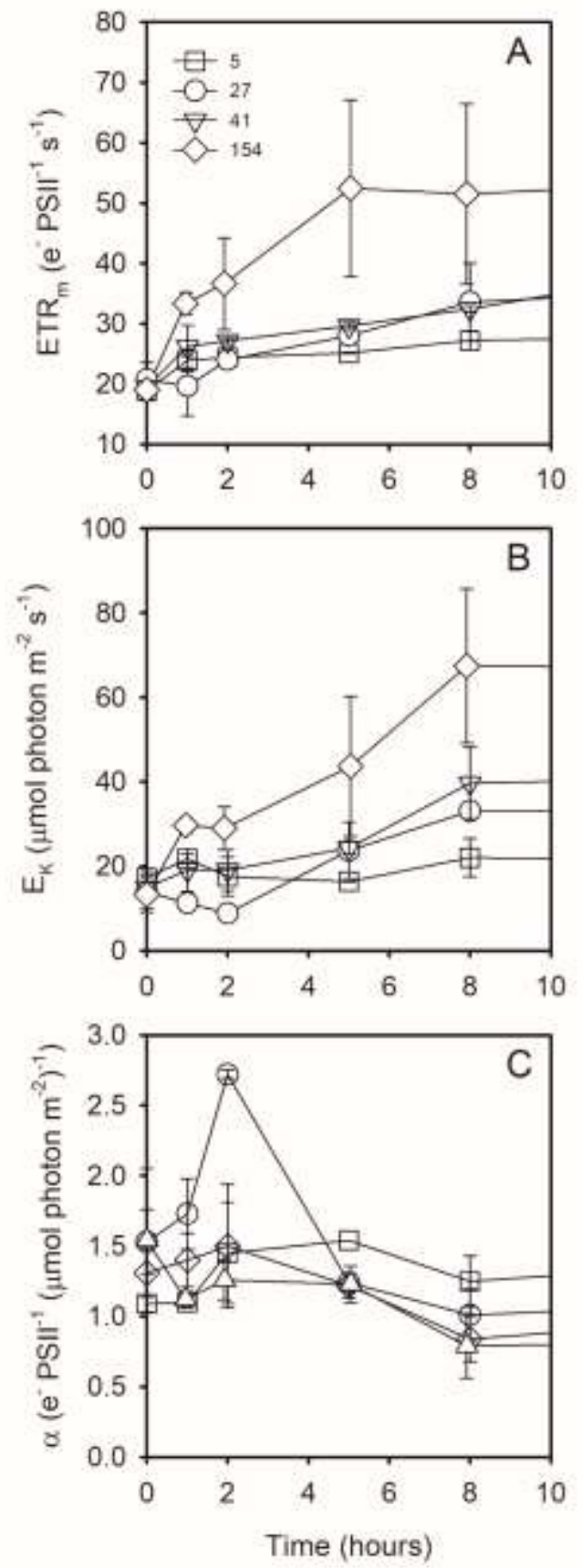

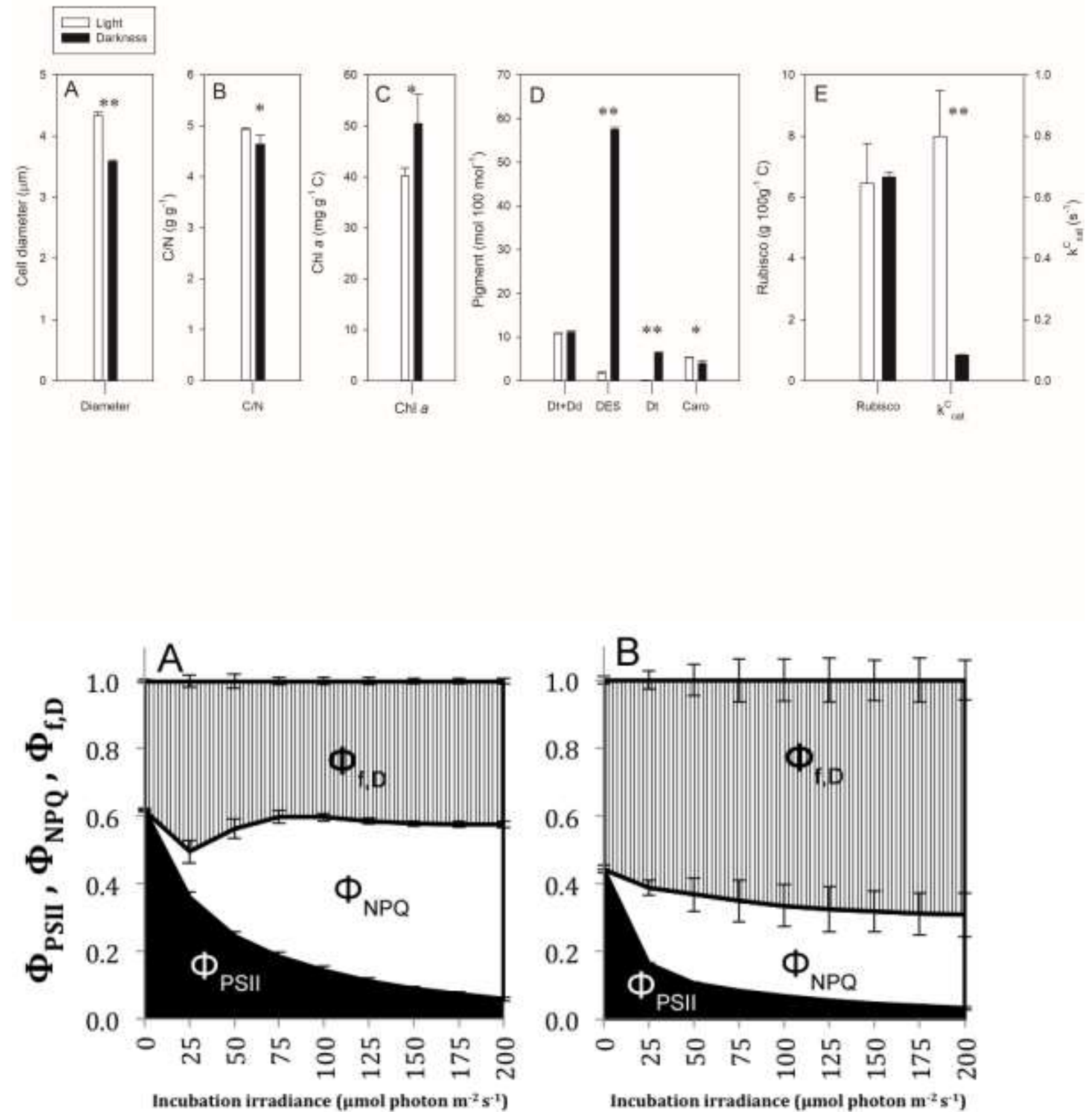

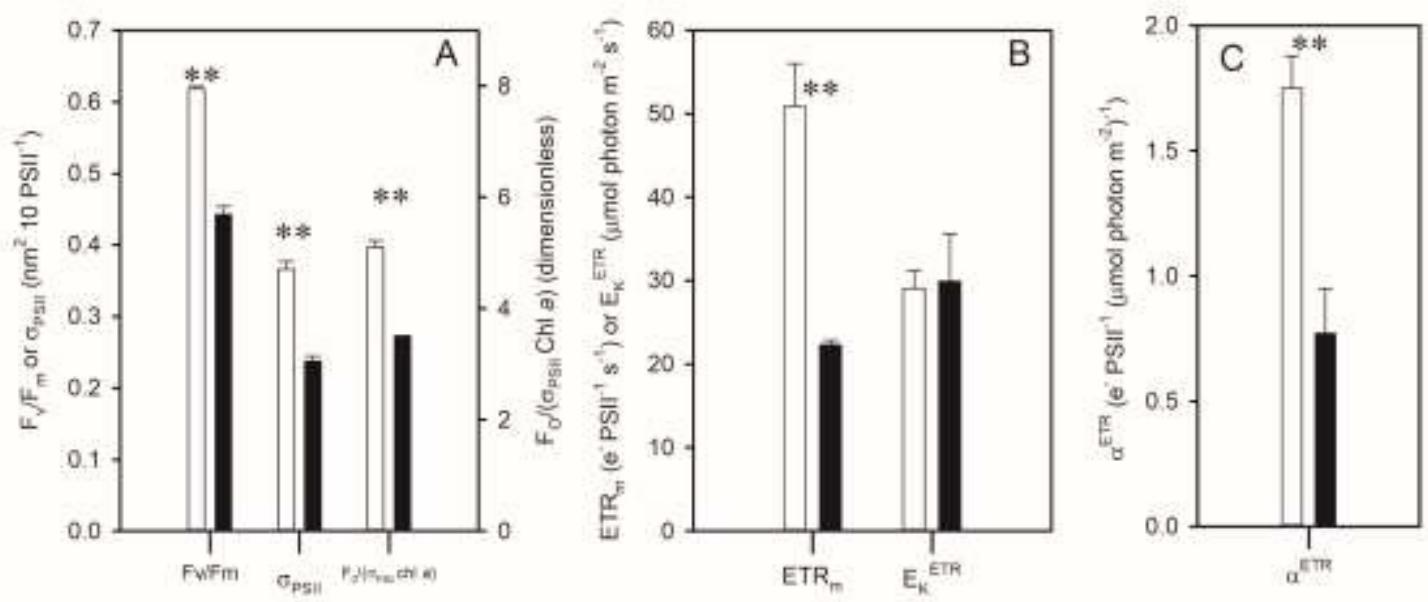

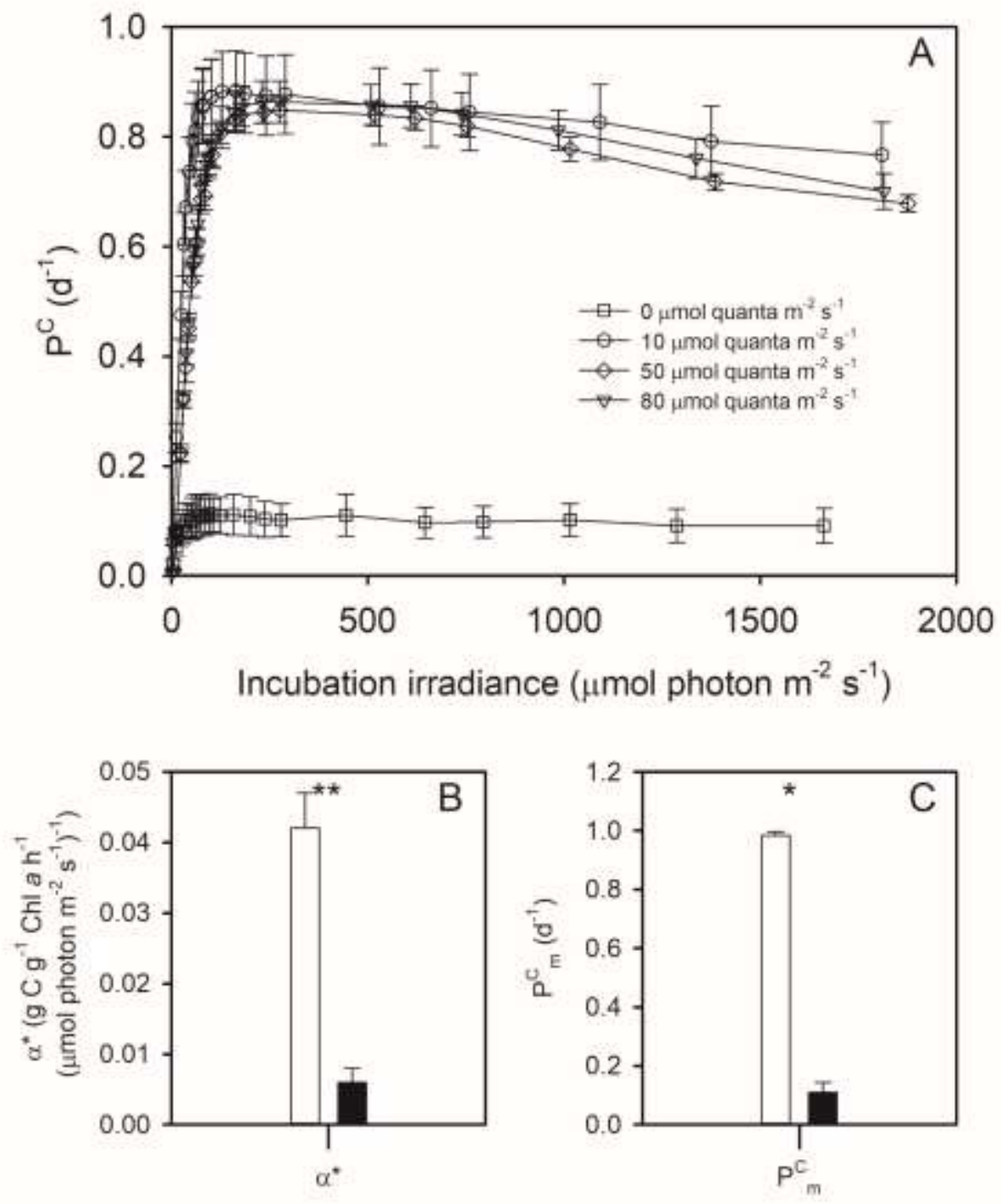


\section{Online resources}

\section{Decoupling light harvesting, electron transport and carbon fixation during prolonged darkness supports rapid recovery upon re-illumination in the polar diatom Chaetoceros neogracilis}

Thomas Lacour ${ }^{1,2^{*}}$ Corresponding author, Thomas.Lacour@ifremer.fr, Philippe-Israël Morin ${ }^{1}$, Théo Sciandra ${ }^{1}$, Natalie Donaher ${ }^{3}$, Douglas A. Campbell ${ }^{3}$, Joannie Ferland ${ }^{1}$, Marcel Babin ${ }^{1}$

1- Takuvik Joint International Laboratory, CNRS (France) \& ULaval (Canada), Pavillon Alexandre-Vachon, Local 2078, 1045, avenue de la Médecine, Département de Biologie, Université Laval, Québec, QC G1V 0A6, Canada

2- IFREMER, Physiol \& Biotechnol Algae Labs, Rue Ile Yeu, F-44311 Nantes, France

3- Department of Biology, Mount Allison University, Sackville NB, Canada E4L1G7

* Present address: Ifremer, PBA, Rue de l'Ile d'Yeu, BP21105, 44311 Nantes Cedex 03, France Tel: 0033 (0)2 40374109

Online resource 1: Diel light cycle applied during light recovery. Irradiance as a function of the time of the day in cultures previously incubated in the dark for 1 month. Triplicate cultures were illumined at each light cycle. Mean diel growth irradiances were 154, 41, 27 and $5 \mu$ mol photon $\mathrm{m}^{-}$ $2 \mathrm{~s}^{-1}$. Maximum growth irradiances (at noon) were 531, 141, 93 and $17 \mu$ mol photon $\mathrm{m}^{-2} \mathrm{~s}^{-1}$.

Online resource 2: Chlorophyll $a$ specific absorption coefficient ( $\mathrm{a}^{*}$ in $\mathrm{m}^{2} \mathrm{mg} \mathrm{Chl} \mathrm{a}^{-1}$ ) versus the wavelength of light in cultures acclimated to $23 \mu \mathrm{mol}$ photon $\mathrm{m}^{-2} \mathrm{~s}^{-1}$ and after 1 month in the dark (A). Relative difference (in \%) between $\mathrm{a}^{*}$ at $23 \mu \mathrm{mol}$ photon $\mathrm{m}^{-2} \mathrm{~s}^{-1}$ and after 1 month in the dark (B).

Online resource 3: $\sigma^{\mathrm{OPT}}{ }_{\mathrm{PSII}}$ in cells acclimated to $23 \mu \mathrm{mol}$ photon $\mathrm{m}^{-2} \mathrm{~s}^{-1}$ (white bars) and after 1 month in the dark (black bars).

Online resource 4: Electron transport rate versus incubation irradiance curves of cells incubated in the dark for one month or acclimated to $23 \mu \mathrm{mol}$ photon $\mathrm{m}^{-2} \mathrm{~s}^{-1}$. Each data point is the mean of measures from 3 different cultures. Error bars represent standard deviations. A model (Platt et al., 1980) was fitted to the data to estimate $\mathrm{ETR}_{\mathrm{m}}, \mathrm{E}_{\mathrm{K}}{ }^{\mathrm{ETR}}, \alpha^{\mathrm{ETR}}$ and $\beta^{\mathrm{ETR}}$ (see Figure 3, 7 and methods). 
Online resource 5: Results of the t-tests comparing photo-physiological parameter at different irradiance of cells acclimated to light and (see statistic section and Figure 4).

\section{Online_resource_1_Lacour et al.}

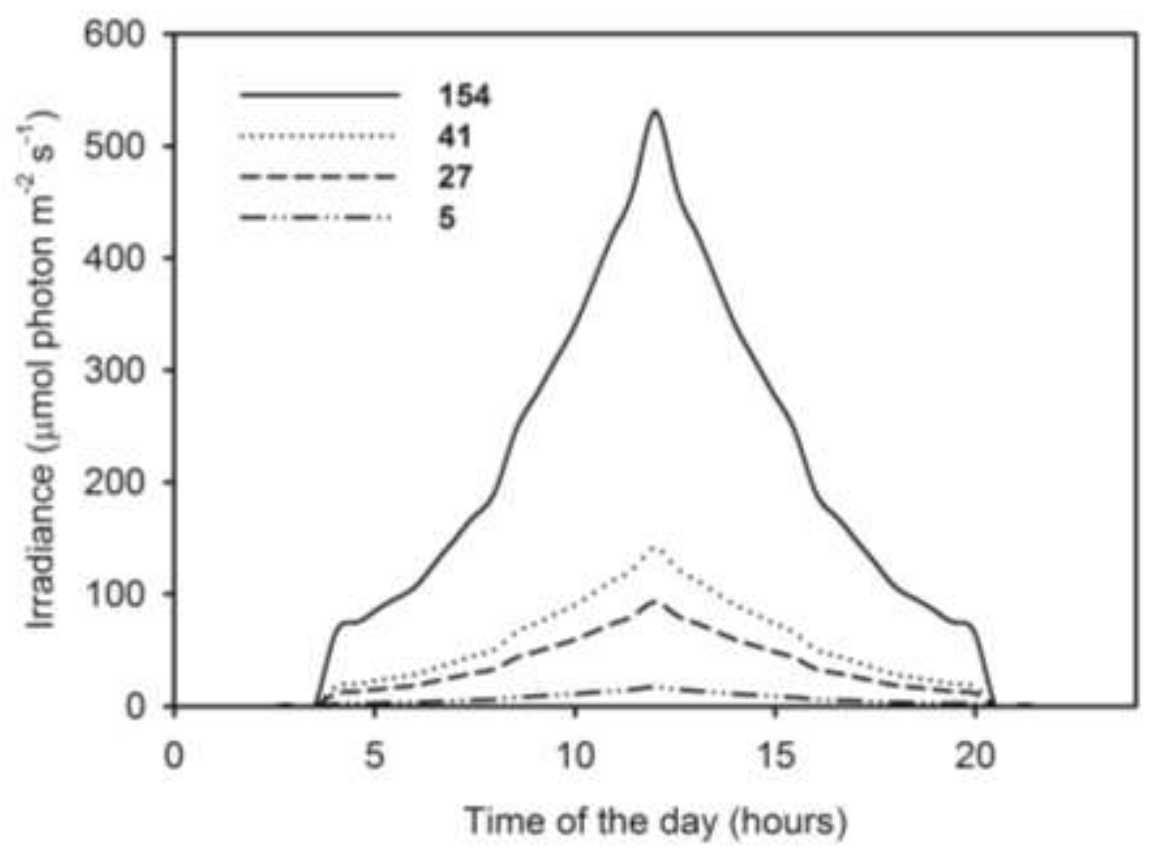

Online resource 1: Diel light cycle applied during light recovery. Irradiance as a function of the time of the day in cultures previously incubated in the dark for 1 month. Triplicate cultures were illumined at each light cycle. Mean diel growth irradiances were 154, 41, 27 and $5 \mu$ mol photon $\mathrm{m}^{-}$ ${ }^{2} \mathrm{~s}^{-1}$. Maximum growth irradiances (at noon) were 531, 141, 93 and $17 \mu$ mol photon $\mathrm{m}^{-2} \mathrm{~s}^{-1}$. 


\section{Online_resource_2_Lacour $e t$ al.}
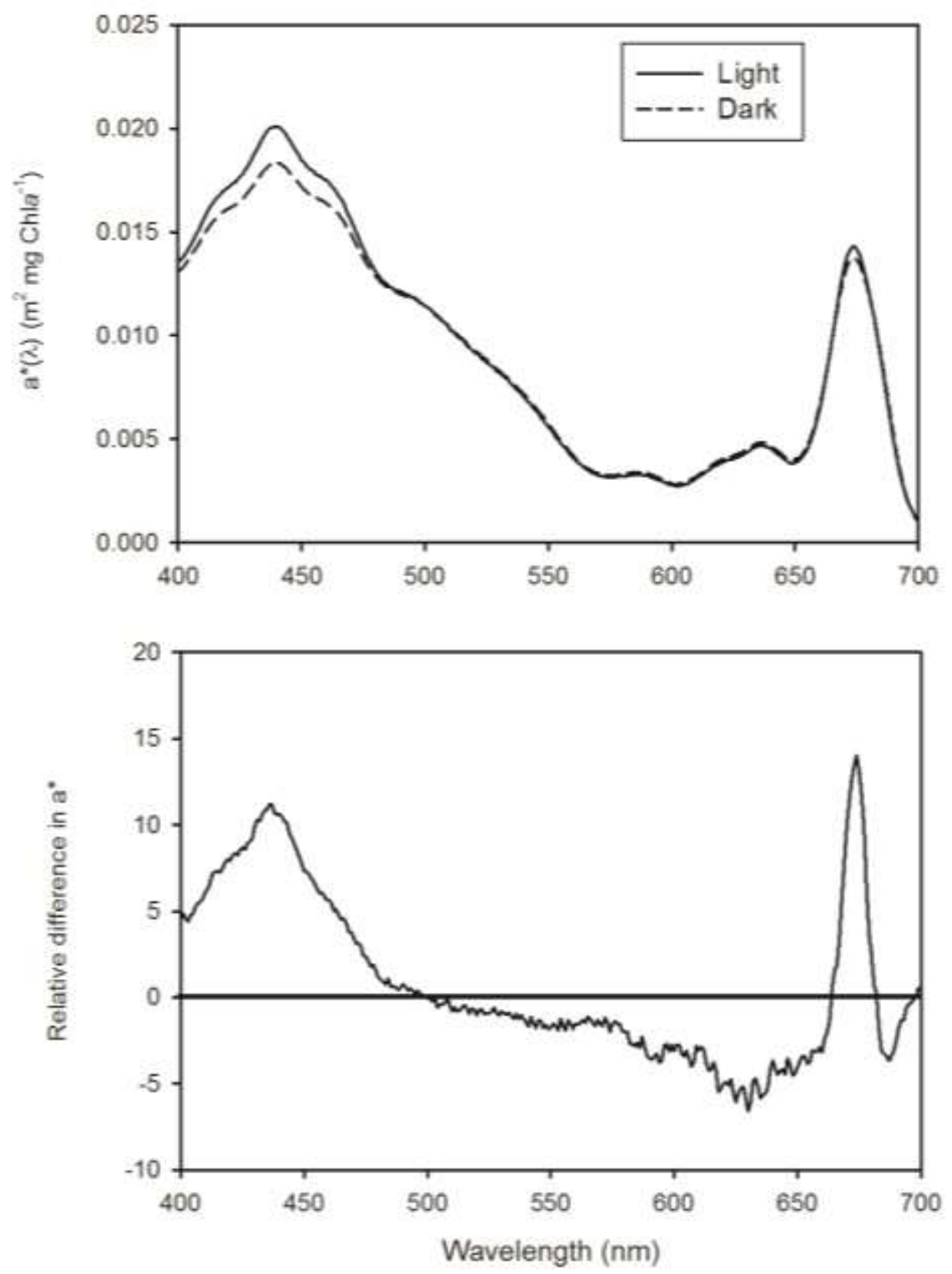

Online resource 2: Chlorophyll $a$ specific absorption coefficient $\left(\mathrm{a}^{*}\right.$ in $\left.\mathrm{m}^{2} \mathrm{mg} \mathrm{Chl} a^{-1}\right)$ versus the wavelength of light in cultures acclimated to $23 \mu \mathrm{mol}$ photon $\mathrm{m}^{-2} \mathrm{~s}^{-1}$ and after 1 month in the dark (A). Relative difference (in \%) between $\mathrm{a}^{*}$ at $23 \mu \mathrm{mol}$ photon $\mathrm{m}^{-2} \mathrm{~s}^{-1}$ and after 1 month in the dark (B). 
Online_resource_3_Lacour et al.

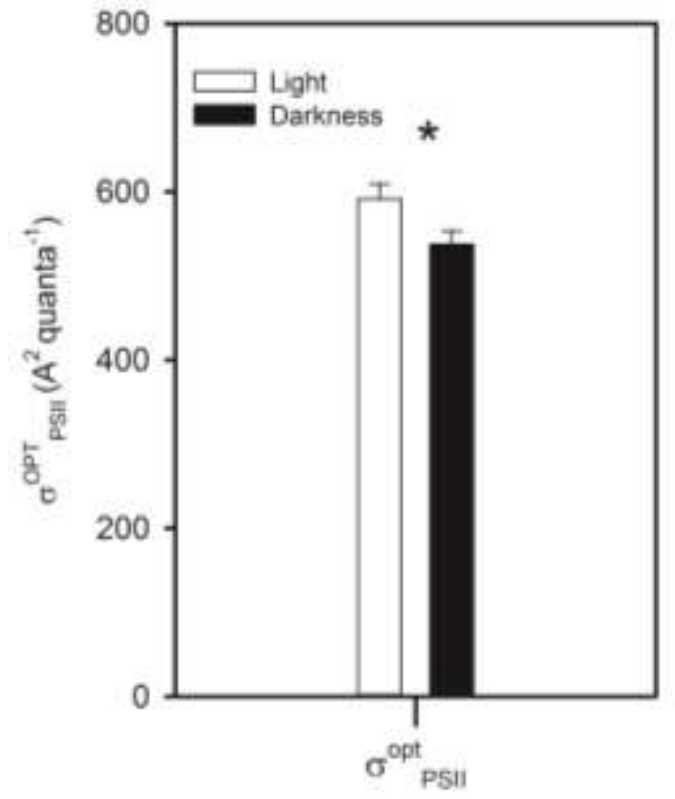

Online resource 3: $\sigma^{\mathrm{OPT}}$ PSII in cells acclimated to $23 \mu \mathrm{mol}$ photon $\mathrm{m}^{-2} \mathrm{~s}^{-1}$ (white bars) and after 1 month in the dark (black bars). 


\section{Online_resource_4_Lacour et al.}

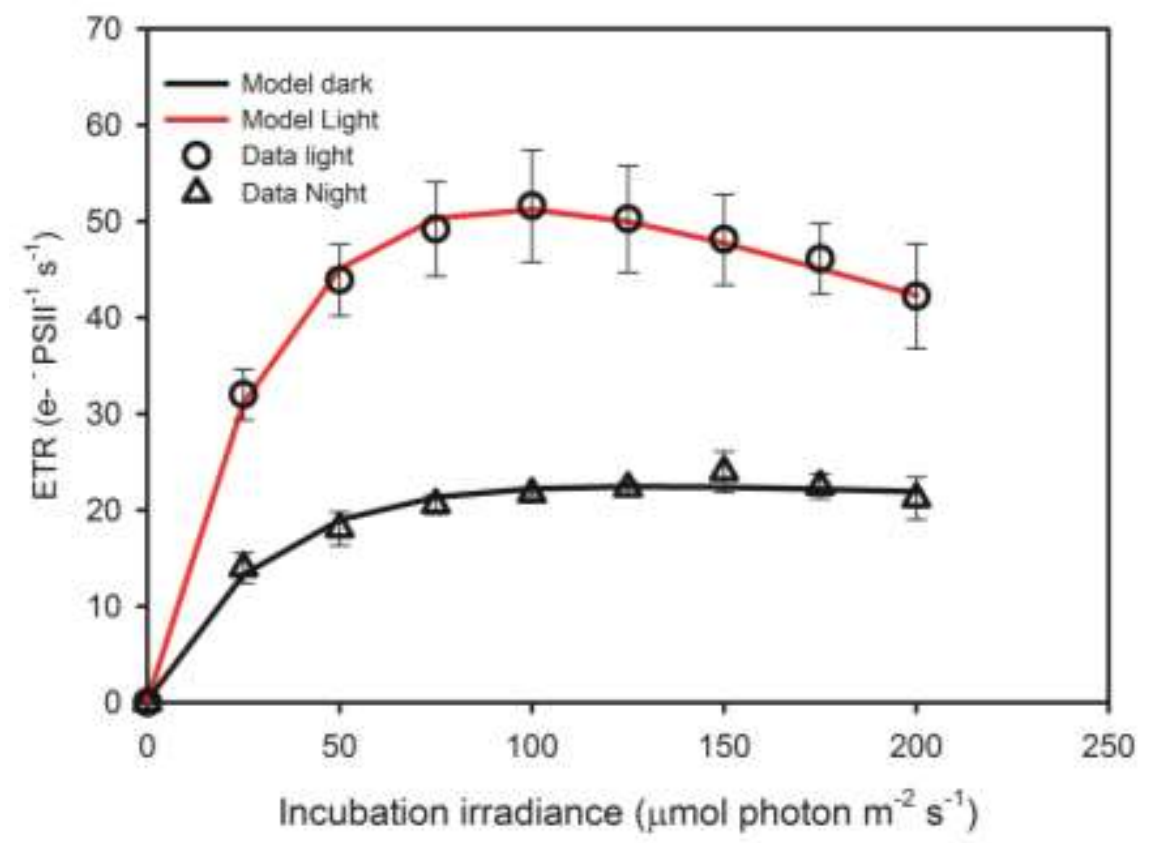

Online resource 4: Electron transport rate versus incubation irradiance curves of cells incubated in the dark for one month or acclimated to $23 \mu \mathrm{mol}$ photon $\mathrm{m}^{-2} \mathrm{~s}^{-1}$. Each data point is the mean of measures from 3 different cultures. Error bars represent standard deviations. A model (Platt et al., 1980 ) was fitted to the data to estimate ETR $, \mathrm{E}_{\mathrm{K}}^{\mathrm{ETR}}, \alpha^{\mathrm{ETR}}$ and $\beta^{\mathrm{ETR}}$ (see Figure 3, 7 and methods). 
Online_resource_5_Lacour et al.

Results of the t-tests comparing photo-physiological parameter at different irradiance of cells acclimated to light and (see statistic section and Figure 5). Results of each test (df, t, p) at each incubation irradiance are presented.

\begin{tabular}{|c|c|c|c|c|c|c|c|c|c|}
\hline & \multicolumn{3}{|c|}{$\Phi_{\text {PSII }}$} & \multicolumn{3}{c|}{$\boldsymbol{\Phi}_{\text {NPQ }}$} & \multicolumn{3}{c|}{$\Phi_{\text {f,d }}$} \\
\hline $\mathbf{E}$ & $\mathrm{df}$ & $\mathrm{t}$ & $\mathrm{p}$ & $\mathrm{df}$ & $\mathrm{t}$ & $\mathrm{p}$ & $\mathrm{df}$ & $\mathrm{t}$ & $\mathrm{p}$ \\
\hline 0 & 9 & 34.55 & $<0.0001$ & $\mathrm{NA}$ & $\mathrm{NA}$ & $\mathrm{NA}$ & 9 & -34.550 & $<0.0001$ \\
\hline 25 & 9 & 14.678 & $<0.0001$ & 9 & -3.505 & 0.0067 & 9 & -7.096 & $<0.0001$ \\
\hline 50 & 9 & 15.869 & $<0.0001$ & 9 & 2.139 & 0.0611 & 9 & -10.084 & $<0.0001$ \\
\hline 75 & 9 & 11.148 & $<0.0001$ & 9 & 7.132 & $<0.0001$ & 9 & -13.592 & $<0.0001$ \\
\hline 100 & 9 & 9.259 & $<0.0001$ & 9 & 10.201 & $<0.0001$ & 9 & -14.832 & $<0.0001$ \\
\hline 125 & 9 & 9.165 & $<0.0001$ & 9 & 11.112 & $<0.0001$ & 9 & -14.174 & $<0.0001$ \\
\hline 150 & 9 & 9.254 & $<0.0001$ & 9 & 13.057 & $<0.0001$ & 9 & -15.326 & $<0.0001$ \\
\hline 175 & 9 & 9.665 & $<0.0001$ & 9 & 13.313 & $<0.0001$ & 9 & -14.734 & $<0.0001$ \\
\hline 200 & 9 & 5.379 & 0.0004 & 9 & 13.361 & $<0.0001$ & 9 & -16.100 & $<0.0001$ \\
\hline
\end{tabular}

Platt T, Gallegos CL, and Harrison WG. 1980. Photoinhibition of photosynthesis in natural assemblages of marine phytoplankton. Journal of Marine Research. 38:687701. 